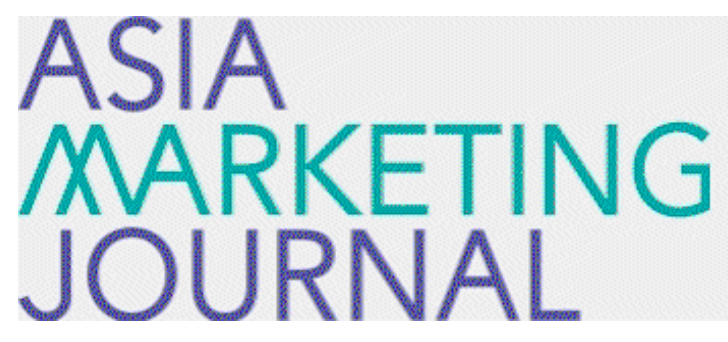

ASIA MARKETING JOURNAL

Volume 22 | Issue 2

Article 2

$7-31-2020$

\title{
Wear Your Heart on Your Sleeve: Exploring Moral Identity as a Moderator Across CSR Authenticity, Consumer Admiration, and Engagement in the Fashion Industry
}

Edward Jung

Suna La

Follow this and additional works at: https://amj.kma.re.kr/journal

Part of the Marketing Commons

\section{Recommended Citation}

Jung, Edward and La, Suna (2020) "Wear Your Heart on Your Sleeve: Exploring Moral Identity as a Moderator Across CSR Authenticity, Consumer Admiration, and Engagement in the Fashion Industry," Asia Marketing Journal: Vol. 22 : Iss. 2 , Article 2.

Available at: https://doi.org/10.15830/amj.2020.22.2.19

This Article is brought to you for free and open access by Asia Marketing Journal. It has been accepted for inclusion in Asia Marketing Journal by an authorized editor of Asia Marketing Journal. 


\title{
Wear Your Heart on Your Sleeve: Exploring Moral Identity as a Moderator Across CSR Authenticity, Consumer Admiration, and Engagement in the Fashion Industry
}

Edward Jung*

Suna La**

\begin{abstract}
A rapidly shifting, hyper-sensitive modern fashion industry, coupled with an increasingly developing global environmental concern, has seen to an ever-imperative role for corporate social responsibility (CSR) to play in the successful operation of fashion companies. This study primarily investigates effective measures for successful CSR implementation in both corporate and consumer domains, looking at Patagonia, an exemplar company with an environmental mission, to understand the central contributions of active consumer engagement to the success of CSR initiatives. We explore consumer admiration as a concept necessary to elevate CSR practices from image maintenance to genuine engagement and advocacy, and how such admiration could be cultivated on the consumerside, investigating perceived CSR authenticity and corporate self-sacrifice as primary determinants. Specifically, we speculate the asymmetric role of consumers' moral identity, revealing that moral identity symbolization positively interacts with both determinants while negatively moderating the relationship of these intentions and consumer admiration. We derive our analysis from diverse international and Korean data, concluding with theoretical and managerial implications for domestic and international companies in pursuit of environmental CSR campaigns that bridge consumer and company, as well as limitations and future research directions.
\end{abstract}

Keywords: Environmental Corporate Social Responsibility (CSR), Consumer admiration, Perceived CSR authenticity, Perceived corporate self-sacrifice, consumer CSR engagement, consumer advocacy, Moral identity internalization, Moral identity symbolization, Patagonia

Department of Politics, Pomona College, California, U.S.A. (edward.jung@pomona.edu)

** Department of Management, Korea National Open University, Republic of Korea

(sunala@knou.ac.kr), Corresponding Author 


\section{Introduction}

The fashion industry is often accompanied in modern media by a cut-throat, competitive nature. While this reputation is no one group's fault, corporations operating within related markets have increasingly found a need to minimize the negative impacts of such a reputation. Many have found a potential solution within corporate social responsibility (CSR), a fairly recent but well-studied concept encompassing positive impact on society within business operations. According to Joo, Miller, \& Fink (2019), CSR is defined collectively as "an organization's endeavors and standing in regard to its societal or stakeholder obligations to increase its positive impact and minimize its negative impact on society (Brown \& Dacin, 1997).

Since a "fast fashion" trend became popular at the turn of the $21^{\text {st }}$ century, the lifecycle of clothes has become shorter, the amount of clothes production a year has soared by 400 times than that of 20 years ago, landfills have increased rapidly, and textile manufacturing processes have severely negatively impacted the environment (Gong, 2017). Such environmental issues have attracted keen interest from consumers and the fashion industry around the globe, which in turn expedited the establishment of ISO 26000, an international standard in practicing CSR in businesses.

Carroll's CSR pyramid model (1991) conceptualizes the hierarchical dimensions of CSR. From the bottom to the top levels lay dimensions of economic, legal, ethical, and philanthropic responsibility. In regard to connecting Carroll's model to the environment, it is important to recognize that environmental issues encompass both legal and ethical responsibilities. Further, when we refer to a company as 'ethical fashion,' it means not only that it doesn't violate established environmental laws but also that it runs its business ethically for the environment. Thus, the concept of 'ethical fashion' goes beyond the observance of regulations; it implies proactive, voluntary works for environmental sustainability. Such a distinction urges a reflection on the phrase "wear your heart on your sleeve" - how can the "heart" of ethics and sustainability be connected to the "sleeves" of our everyday fashion?

Patagonia is widely known as one of the first movers to initiate environmentally responsible practices proactively among fashion companies. The firm, a California-based outdoor clothing company, registered as the state's first benefit corporation (B Corp.) in January 2012. When asked about it, the founder, Yvon Chouinard, said that he "felt morally obligated to do something about it” (Wetherille, 2019). Patagonia asks its customers to practice what it calls the four R's: repair, reuse, recycle, and reduce (Yoo, 2012; Wetherille, 2019).

Existing literature shows that most consumers are aware of the importance of environmental 
sustainability (e.g., Hong \& Kim, 2014), have relatively positive attitudes towards environmentally responsible companies, and are willing to pay more money for them (Lee \& Kim, 2011; Jeong \& Rhee, 2018). However, fashion consumers' concern for the environment is directly linked to neither purchase nor post-purchase behaviors such as those supported by repair, reuse, or environment-friendly disposal (e.g., Hong \& Kim, 2014). As Patagonia stresses, the four R's are necessary to lessen harms to the environment, but such company-centric actions are not sufficient. To lessen environmental harm, consumers should put efforts in action. Patagonia says that they support their customers, to join the company in reducing their personal carbon footprints. They know that the final ' $R$ ' is to reduce, an action at the core of the solution to environmental crisis.

Unfortunately, this is the most difficult one to communicate consumers (Wetherille, 2019). As such, CSR communication is important as a bridge, to lead the consumers to such positive action. However, most Korean companies have been using their CSR activities as tools for improving public relations or brand image (Lee, Ma, \& Lee, 2017). To switch such practices, companies in the Korean fashion industry should learn how to exert their efforts to make their customers more engaged in the environmental campaigns in tune with the companies themselves.

To link consumers' environmental concerns to firms' environmental CSR, companies should motivate consumers to engage in their CSR programs and encourage them to advocate for them. Consumer engagement in CSR will then be followed by improvements in revenues. Past literature demonstrates that customer loyalty and brand relationship quality would increase after participation in CSR programs (Cha, Yi, \& Bagozzi, 2016; Jarvis, et al., 2017; Lo, 2020; Ruiz de Maya, Lardín-Zambudio, \& LópezLópez, 2016).

To shed light on implications for successful CSR implementation in the fashion industry, we have investigated the psychological mechanisms underlying consumers' active behavioral responses to a company's CSR initiatives. We have selected an exemplary company, Patagonia, to investigate the determinants of consumers' active behavioral responses, such as CSR engagement, advocacy, and buying intention, in relation to the firm's environmental initiatives.

Past literature has emphasized CSR authenticity as a major factor of CSR success from the consumer perspective. However, to make consumers act for the cause, perception is not enough. After all, there is much more passive than active in most, if not all, instances of perception. On the contrary, a strong emotional drive could motivate people to act (Frijda, Kuipers, \& Tershure, 1989; Lazarus, 1991). As a strong emotional drive, we adopt a construct of 'consumer admiration' for a firm. Admiration arises from experiencing appreciation, awe, esteem, and respect for an appraised target (Algoe \& Haidt, 
2009; Ortony, Clore, \& Collins, 1988) and it can be aroused by a target's moral acts (Keltner \& Haidt, 2003). Based on previous literature, He, Chao, \& Zhu (2019) conducted an empirical study with employees and revealed that admiration could increase the employees' engagement in cause-related marketing. Likewise, we expect there to be a positive relationship between consumer admiration and CSR engagement, among other active behavioral intentions for the firm.

In addition, corporate self-sacrifice will be examined as a determinant of consumer admiration. Alongside authenticity, self-sacrificial leadership can earn followers' admiration for the leader or the company (Bélanger, Caouette, Sharvit, \& Dugas, 2014; O’Hare \& Wood, 1994). Specifically, we’ll consider consumer's moral identity internalization and symbolization respectively to investigate their moderation effects among constructs, inspired by empirical evidences in past literature (He et al., 2019; Winterich, Aquino, Mittal, \& Swartz, 2013). Since the CSR engagement, advocacy, and purchasing are explicit acts to demonstrate consumers' moral character to others, moral identity symbolization would come into play in forming future behavioral intentions (Winterich et al., 2019). Moral identity internalization would play a promoting role in increasing admiration (He et al., 2019).

Using these constructs, we have built a structural equation model and tested hypotheses of causal relationships. Building on, the moderation effects of moral identity internalization in forming customer admiration and moral identity symbolization in forming behavioral intentions were tested accordingly.

\section{Theoretical Background and Hypotheses}

We argue that the success of CSR campaigns depends on consumer engagement. We begin by pointing out that prior literature on consumer engagement/participation in CSR activities are abundant, and reflect on key segues into the scope of our work. For example, Ruiz De Maya et al. (2016) presented that when the campaign was participatory, sensory pleasure seekers had greater perceptions of CSR activities than when the campaign was non-participatory. It was argued that enabling consumer participation would bring more positive outcomes to firms. Mattila \& Hanks (2012) summed up factors known to enable consumers to participate in CSR programs through a literature review; prominent factors discovered were the proximity of target charity (Hoeffler \& Keller, 2002; Sen, Du, \& Bhattacharya, 2009) and status and empathy (Graziano et al., 2007). They reported that these combined factors determined consumers' participation intention in CSR programs (e.g., donation). Line, Hanks, \& Zhang 
(2018) proposed a "social servicescape" as a determinant in the restaurant setting. They showed that the perceptions of similarity in such a servicescape (i.e., congruence with other customers in the consumption environment) can affect decisions to participate in donationbased CSR programs. Mattila, Wu, \& Choi (2016) suggested a combined effect of consumers' sense of power and a firm's expression of gratitude towards participation was found significant in matching donation situations.

As depicted above, however, most previous studies on consumer engagement/participation have focused either on consumers' psychological traits or the characteristics of individual CSR programs. On the other hand, there is noticeably less literature on the emotional motivations that drive consumers to engage in a firm's CSR initiatives, and the determinants that help make up the conceptual bridge from firm to consumer across the CSR backdrop. Emotional motivations, of course, are highly important; they serve as strong driving factors in getting a person actively involved in an action, inducing consumers to engage in/advocate for CSR initiatives and getting them to resist purchasing options from competitors.

Thus, our big question is two-fold: how can we construct, for a model, independent variables that can begin the chain of influence on CSR engagement and, on the other hand, mediating variables that are meaningfully different from these independent variables? Further, another question will rise later: how can we ensure these mediating variables mean something significant in the model, and eliminate questions of preexisting awareness or cross-application, as in the relationship between perceptions about companies and perceptions about moral identity.

To begin our approach to an answer to the first question of constructing unique independent variables, we start with Aaker, Galvinsky, \& Vohs (2012), who argue that the emotion of admiration in branding is a key predictor of a consumer's willingness to engage with the organization and buy its brands. They suggest that consumer admiration for a brand can be cultivated. They also argue that "admiration appear to play a more proximal role in changing behavior and spurring consumers to want to buy from the firm." (p.193). This argument is in line with previous literature on admiration. Admiration is known as one of many otherpraising emotions that motivates a person to emulate the admired target (Algoe \& Hadt, 2009). Admiration draws attention and followers, and followers, in turn, are inspired by, motivated to build a relationship with, and to learn by copying the respected target (Fredrickson, 1998; Thrash \& Elliott, 2004).

Then, what factors arouse consumer admiration in the CSR context? According to Michie \& Gooty (2005), authenticity and self-sacrifice are conceived as high self-transcendent values of inspirational styles of leadership in terms of morality. The researchers stressed that "authentic 
leaders strive to do what is right and fair for all stakeholders and may willingly sacrifice self-interests for the collective good of their work unit, organization, community, or entire society (Bass \& Steidlmeier, 1999; Burns, 1978; Howell \& Avolio, 1992; Luthans \& Avolio, 2003)" (p.443).

One may initially argue that sincerity, authenticity, and admiration are all consumer perception variables, providing ample skepticism about the feasibility of causal relationships forming among such perceptual variables. However, under the contexts of leadership and CSR, admiration, as we will continue to theorize in the following sections, is uniquely causally related to both authenticity and sincerity of self-sacrifice.

As such, we believe it is worthy to investigate consumer admiration as an emotional motivator to drive consumers into active behaviors. To do so, we should explore the formation process of consumer admiration by considering CSR authenticity and corporate self-sacrifice as its antecedents and CSR engagement, advocacy, and relative buying from an admired company as its outcomes. We build our model out from this "admiration core," and explore reasons for focusing on certain determinants and factors over others (namely, authenticity and selfsacrifice) in the following sections.

\subsection{CSR Authenticity and Admiration}

Aaker, Galvinsky, \& Vohs (2012) suggested warmth and competence as determinants of admiration in brands. Then, in the CSR setting of the fashion industry, what are the most substantial elements that cultivate consumer admiration for a company? According to Kim \& Choo (2019), in fashion markets, perceived authenticity plays a crucial role in converting consumers to enthusiastic fans. It subsequently gets consumers engaged with and devoted to the target brand (Pentecost \& Andrews, 2010). For this, we can refer to the case of Patagonia. Thorelli (2016) mentioned that Patagonia, as one of the most well-known benefit corporations (B corp.) in the fashion industry, has been acknowledged as an attractive role model due to their presentation of authenticating their status as a socially responsible entity pursuing positive impact on society and environment. This remark provided a lesson that CSR success is heavily dependent on how consumers perceive its authenticity (Mazutis \& Slawinski, 2014). With regard to CSR or ethical management in Korea, Patterson \& Rowley (2019) criticized that, since the early 1990's, executives or founders have often continued to act as poor role models instead of key sources of ethical guidance. The business climate of Korea has changed considerably for the better as of late, but its practices have not yet met consumers' expectations (Cone, 2013). Consumers expect 
authenticity, but not the wash-up of brand image through a nominal, just-for-show CSR strategy. This strongly suggests that 'true self' matters (McShane \& Cunningham 2012). Consumers markedly dislike hypocritical stances. According to Alhouti et al. (2016), perceived CSR authenticity is defined as "the perception of a company's CSR actions as a genuine and true expression of the company's beliefs and behavior toward society that extend beyond legal requirements" ( p. 1243). There are two conditions for the consumers' perspective of authentic CSR: the activities must first be consistent with a firm's observed identity, and in addition, corporations must 'walk the talk' and actually match rhetoric with action. That is, perceived CSR authenticity is an outcome of evaluation that combines the rightness of motives as well as the rightness of activities (Algoe \& Hadt, 2009).

Joo, Miller, \& Fink (2019) identified perceived CSR authenticity as a multidimensional construct (i.e., community link, reliability, commitment, congruence, benevolence, transparency, and broad impact) and discovered its positive relationships with consumers' behavioral intentions such as to recommend, support, relate, and purchase. The researchers, however, did not examine the mediator variables that would link from CSR authenticity to behaviors. We suggest admiration as a mediator because the importance of authenticity is also found in admiration studies. For example, authentic leadership appears associated with moral consideration and commands admiration, respect, and emulation from followers (Novicevic et al., 2005).

On the aforementioned theoretical background, we propose consumer admiration as a mediator in the link from perceived CSR authenticity to behavioral intentions. Applying the basic sequence of psychological systems of cognitive appraisal theory, it is reasonable to consider CSR authenticity as a cognitive appraisal, that it produces feelings of admiration, and that it then ends in behaviors (Aker, Galvinsky, \& Vohs, 2010).

Hypothesis 1: Consumer's perceived CSR authenticity will positively affect consumer admiration for the company.

\subsection{Corporate Self-Sacrifice and Admiration}

The concept of CSR originally includes the self-sacrifice of shareholder profit, according to Milton Friedman's arguments in the late $20^{\text {th }}$ century. This means corporate self-sacrifice requires more than just staying ethical. This broadened perspective for CSR is supported in the modern business world (Dodd, 1932). Le Menestrel (2002) differentiates a 'sacrificial business' pursuing causes despite costs from an 'ethical business' seeking profit in an ethical way. This argument supports why customers appreciate moments of corporate self-sacrifice 
such as suffering losses or risking lessened profits for successful CSR implementation (Ahn, 2015; O’Hare \& Wood, 1994).

Patagonia donates one percent of their revenue (not one percent of their profit) for environmental sustainability and started its One Percent donation initiative in 2002 for environmental nonprofits. They have also rolled out ads stating "don't buy this jacket" with an image of their most popular fleece, in efforts to reduce consumption. Patagonia has also focused since 2005 on Worn Wear, an online store for used Patagonia clothing that stresses extending the life of their used gear through repair and recycling to cut down on consumption. These campaigns are evidence that the company has actively sacrificed its revenue to fight for environmental causes.

Due to their model of sacrificial leadership, Patagonia has become one of the most admired companies in the world (Leleux \& van der Kaaij, 2018). Similarly, in 2007, Panasonic recalled its malfunctioning heaters which were sold for almost two decades. Panasonic made extensive efforts to collect the heaters by spending over 30 billion yen. This extensive and responsible effort, in turn, resulted in high consumer admiration for the company among Japanese consumers (Murakami, 2009). These business cases reflect how consumer admiration can be created when consumers think of a company accomplishing genuine social responsibility goals despite the sacrifice of its profit.
Contrary to the lack of interest in corporate self-sacrifice among marketing academics, organizational researchers have endeavored into self-sacrificial leadership. The literature demonstrates that sacrificial leadership brings positive emotional and motivational outcomes to an organization (Choi \& Mai-Dalton, 1998; De Cremer, 2006; De Cremer \& Knippenberg, 2005) such as consumer admiration (Aaker, Galvinsky, \& Vohs, 2012).

Indeed, self-sacrifice has a long history of promoting veneration. For example, perceptions of meaning drive individuals' greater willingness to donate to charity under the suffering (vs. fun) condition (Olivola \& Shafir, 2013). Encountering a self-sacrificial person for a greater good can lead to people feeling respect towards them, as we might conjecture from religious leaders and contexts. However, it is noteworthy that admiration for self-sacrifice is not restricted to religious contexts. Moral leaders usually attain veneration from public (Dugas et al., 2016). Thus, we can predict that a CSR-performing company will attain admiration from consumers if it is perceived as self-sacrificing for the cause.

Hypothesis 2: Consumer's perceived corporate self-sacrifice will positively affect consumer admiration for the company. 


\subsection{CSR Engagement, Advocacy, and Buying Intention Based on Admiration}

Consumer admiration is an emotional reaction to CSR (He, Chao, \& Zhu (2019). People feel admiration when they witness "virtuous acts" of moral exemplars, then are "motivated to try to emulate the admired target," sometimes even "desire to be connected with the target" (Immordino-Yang \& Sylvan, 2010, p.84). This argument is echoed in prior studies emphasizing that admiration serves as a motivator factor to reciprocate, relate, and emulate the admired target (Aaker, Galvinsky, \& Vohs, 2012; Algoe \& Hadt, 2009; Fredrickson, 1998; Thrash \& Elliott, 2004). All these responses are interpreted to consumers' CSR engagement, advocacy, and relative purchase.

If the CSR goal can only be effectively accomplished through the combined endeavors of both a company and its consumers, then it is very important to encourage consumers to engage in the campaigns. Without consumers' engagement, CSR initiatives can hardly succeed. In fact, Patagonia endeavors to get customers engaged in the CSR process (Esposito \& Soufani, 2016). Patagonia works successfully with consumers to reduce waste. For example, the company has partnered with DIY website iFixit to teach consumers how to repair their clothing, also offers a repair program for their customers for a modest fee. We believe such engagement of consumers is an outcome of admiration for the company. Patagonia's CSR practice can be supported by the argument put forth by Jarvis et al. (2017). They argue that no longer are customers regarded as passive recipients of marketing cues; rather, they are involved in interactive processes allowing organizations to build deeper and more meaningful sustainable interactions with their customers, particularly placing emphasis on customer engagement in activities beyond purchase, such as value co-creating engagement with the company.

As in an organization setting, consumers are expected to identify themselves more intensively with a respectful, socially well-regarded, and admired organization (Barnett, Jermier, \& Lafferty, 2006; De Roeck \& Delobbe, 2012; Peterson, 2004). As shown in the organizational identification measures (Mael \& Ashforth, 1992), the kernel of identification is similar to the concept of advocacy. Consumers advocate for a company they admire. Du, Bhattacharya, \& Sen (2010) proposed a conceptual framework of CSR communication, wherein reputation moderates CSR outcomes such as advocacy behaviors, as well as purchase and loyalty. Castro-González et al. (2019) provided empirical evidence that a food company's social, ethical, and environmental CSR yielded a significant effect of consumer admiration on consumer advocacy behaviors.

Relative purchase despite the premium price 
or over the alternatives is another outcome of consumer admiration. As another piece of evidence from the food industry, Kim (2017) showed that when a company demonstrated proactive environmental CSR initiatives, respondents did not distinguish between prices and showed generally positive intent to support and purchase from the company because the company's level of environmental sustainability influenced people's evaluation of their products' value. This tendency indicates that consumers prefer purchasing from more environmentally responsible companies that they admire (Bortree, 2009).

In sum, consumer CSR engagement, advocacy, and relative purchase can be considered the behaviors of a kind of closure or reciprocity to the firm that consumers admire, as consumer admiration is composed of awe, gratitude, and elevation (complimentary positive moral emotions) elicited by a firm's virtuous performance of CSR (Xie, Bagozzi, \& Grønhaug, 2019). So, it is natural that consumers show higher intention to resist negative messages regarding the firm, recommend, and invest in the company on top of purchasing. This tendency demonstrates how consumer admiration can evolve into an enduring partnership with a firm. Based on the theoretical background reviewed so far, we propose the following hypotheses.

Hypothesis 3: Consumer admiration will positively affect consumer CSR engagement.
Hypothesis 4: Consumer admiration will positively affect consumer advocacy.

Hypothesis 5: Consumer admiration will positively affect consumer buying intention.

\subsection{The Moderation of Moral Identity}

To preface a discussion of introducing moral identity as a moderator, it is important to recognize that a strong perception of authenticity and sacrifice does not necessarily equate to an equally strong awareness of individual moral identity. First, from a categorical standpoint, the first degree of perception is from a consumer, towards a company or campaign, whereas the second degree is from a consumer, towards that same consumer. When it comes to evaluating individuals' perceptions of their own moral identity, such awareness is inherently of a different nature from other, outward-facing perceptions, necessitating a separate approach for our analysis. Second, as we expand upon below, we employ the term "moral identity" throughout our research to stand for a broad archetype spanning personal self-concept, role model theorization, and self-sourced emotion, as gathered from a variety of different studies conducted thus far. Thus, we find that moral identity carries important weight as a unique, moderating variable and develop its significance in the following paragraphs.

According to Cha, Yi, \& Bagozzi (2016), the motives of consumers' CSR participation can 
be interpreted as self-signaling. Self-signaling works in two-directions: the self and the other. In fact, moral identity is a two-faceted construct: internalization and symbolization. However, the level of moral identity symbolization does not necessarily correspond to one's level of internalization according to Aquino \& Reed's (2002) model. This model indicates that symbolization and internalization are two factors in constructing a person's moral identity. This implies that it is possible that there are people who have high in moral identity internalization with low symbolization, and vice versa.

Interestingly, Aquino \& Reed (2002) discovered that a person's self-concept was positively correlated with the internalization dimension of the explicit measure of moral identity. To the contrary, symbolization appears to be more strongly related to the outcomes than is internalization. Aquino \& Reed explained these differential patterns by putting forth an interpretation that "symbolization was more strongly correlated to those outcomes or measures that had a self-presentational or public dimension," because in their study "symbolization was correlated with a measure of impression management, indicating its potential susceptibility to self-presentational concerns" (p.1437).

Their findings allow us to understand the two different working mechanisms of moral identity internalization and symbolization as two different motivators to induce consumers' cause-related behaviors. One is the desire for maintaining self-consistency and the other is the motivation for symbolic interactionism (Winterich et al., 2013). The desire for maintaining self-consistency can be applied to the formation process of consumer admiration among those high in moral identity internalization. Admiration is the most representative example of the appreciation emotions (Ortony et al., 1988), which are "sometimes used in ordinary English as a response to moral exemplars" (Algoe \& Haidt, 2009, p.107). This means that admiration is a self-sourced emotion which inspires a person to desire for proximity towards the admired target since the person believes the target to be a role model (Lockwood \& Kunda, 1997, 1999). To feel admiration for a company on the grounds that the company is a moral exemplar seems consistent with one's moral self-concept being among those high in moral identity internalization. When following their moral self-concept, it is natural for them to feel high admiration for a morally respectable model.

To support the rationale, it is worthwhile to revisit the study of Castro-González et al. (2019). The researchers examined not only the mediating role of the emotion of admiration in the relationship between consumer perception of CSR and advocacy behaviors but also the moderating role of the consumer moral virtue of integrity in the relationship between CSR perception and feelings of admiration. The results showed that the company's CSR 
practices positively influence consumer advocacy behaviors both directly and indirectly through consumer admiration for the company. Consumer integrity moderates the relationship between consumer perception of CSR and admiration. Specifically, CSR practices have a stronger admiration effect on consumers who are high in integrity. Integrity lies more on the field of moral identity internalization. So, we can predict that internalization will work like integrity in our model.

Put all together, we can expect moral identity internalization to have a positive interaction effect with both perceived authenticity and corporate self-sacrifice in forming consumer admiration based on a consistent consumer motivation of moral self-concept. Also, we can expect that moral identity symbolization has a positive interaction effect with both perceived authenticity and corporate self-sacrifice in increasing cause-related acts such as CSR engagement, advocacy, and buying from an ethical brand. Symbolic interactionism explains the synergistic effect of moral identity symbolization which motivates consumers' expressive behaviors for the environmental cause.

Hypothesis 6A: Consumer moral identity internalization will have a positive interaction effect with perceived CSR authenticity on consumer admiration.

Hypothesis 6B: Consumer moral identity internalization will have a positive interaction effect with perceived corporate self-sacrifice on consumer admiration.

Hypothesis 7A: Consumer moral identity symbolization will have a positive interaction effect with perceived CSR authenticity on consumer's behavioral intentions.

Hypothesis 7Aa: Consumer moral identity symbolization will have a positive interaction effect with perceived CSR authenticity on consumer's CSR engagement.

Hypothesis 7Ab: Consumer moral identity symbolization will have a positive interaction effect with perceived CSR authenticity on consumer's advocacy.

Hypothesis 7Ac: Consumer moral identity symbolization will have a positive interaction effect with perceived CSR authenticity on consumer's buying intention.

Hypothesis 7B: Consumer moral identity symbolization will have a positive interaction effect with perceived corporate self-sacrifice on consumer's behavioral intentions.

Hypothesis 7Ba: Consumer moral identity symbolization will have a positive interaction effect with perceived corporate self-sacrifice on consumer's CSR engagement.

Hypothesis 7Bb: Consumer moral identity symbolization will have a positive interaction effect with perceived corporate self-sacrifice on consumer's advocacy. 
Hypothesis 7Bc: Consumer moral identity symbolization will have a positive interaction effect with perceived corporate self-sacrifice on consumer's buying intention.

As reviewed above, moral identity symbolization works under the umbrella of symbolic interactionism, which is different from the role of internalization. Winterich et al. (2013) tested the different natures of internalization and symbolization in time volunteering settings by examining the differential roles of each moral identity factor. According to their study, in the recognition condition (volunteer's name listed on a website), moral identity symbolization increased volunteering for those low in internalization, but not for those high in internalization. This finding implies that moral identity symbolization has a positive moderation effect in converting one's moral characteristics to acts among those who are less internalized with morality. The researchers viewed moral identity internalization as the private dimension of moral identity and moral identity symbolization as the public dimension of moral identity that "represents the degree to which people tend to convey their moral identity externally through their actions in the world” (p. 761).Cha, Yi, \& Bagozzi (2016) examined the relationship among CSR-brand fit, brand identification (personal identification versus social identification), and brand loyalty by speculating the moderation effect of consumer's CSR participation. They reasoned based on Ryan
\& Deci (2000) that personal identification reflecting private self would be more similar to intrinsic rewards whereas social identification is relatively closer to extrinsic rewards, which displays the moral self-image under the condition of the social gaze of "the other."

Taken together, moral identity internalization appears as the private dimension of moral selfconcept, associated with an intrinsic reward that doesn't require a reward from outside. However, moral identity symbolization is more similar to the public dimension of moral selfconcept, thus associated with an extrinsic reward obtained from the outside. Then, what will happen when moral identity symbolization interacts with consumer admiration in forming outwardly behavioral intentions? The anticipated results will depend on the perspective on the nature of consumer admiration.

Based on the studies above mentioned thus far, consumer admiration is a strong innermost emotion that can induce the subject to emulate the target whom he/she admires. In other word, admiration is an intrinsic motivator that can be self-rewarded. Thus, consumers who highly admire the target company will voluntarily participate in the cause-related campaign that the company is devoted to. This means that there is less need for other tokens for the good deed which signalize a consumer's morality when consumer admiration comes to play. Similar to the findings of Winterich et al. (2013), consumers with high moral identity symbolization 
will be more likely to indulge into outwardly activities for environmental causes, compared to those who are low in symbolization; however, this tendency will be affected by their level of admiration for the company. As admiration increases, behavioral intentions for the cause will be less influenced by the level of moral identity symbolization. Contrarily, consumers with higher moral identity symbolization will have a higher tendency to act for cause-related activities under the condition of their lower admiration for the company. That is, relatively higher moral identity symbolization serves a motivator for consumers to outwardly signalize their morality by their cause-related actions. However, this type of signaling motivation will decrease as the level of admiration increases. Consumer admiration in our model serves an intrinsic motivator to act for or emulate the admired company. Thus, the interaction effect of moral identity symbolization with consumer admiration on cause-related behavioral intentions is expected to be negative.

Hypothesis 8: Consumer moral identity symbolization will have a negative interaction effect with consumer admiration on consumer's behavioral intentions.

Hypothesis 8a: Consumer moral identity symbolization will have a negative interaction effect with consumer admiration on consumer's CSR engagement.

Hypothesis 8b: Consumer moral identity symbolization will have a negative interaction effect with consumer admiration on consumer's advocacy.

Hypothesis 8c: Consumer moral identity symbolization will have a negative interaction effect with consumer admiration on consumer's buying intention.

The conceptual research model which reflects

〈Figure 1〉 Conceptual Research Model

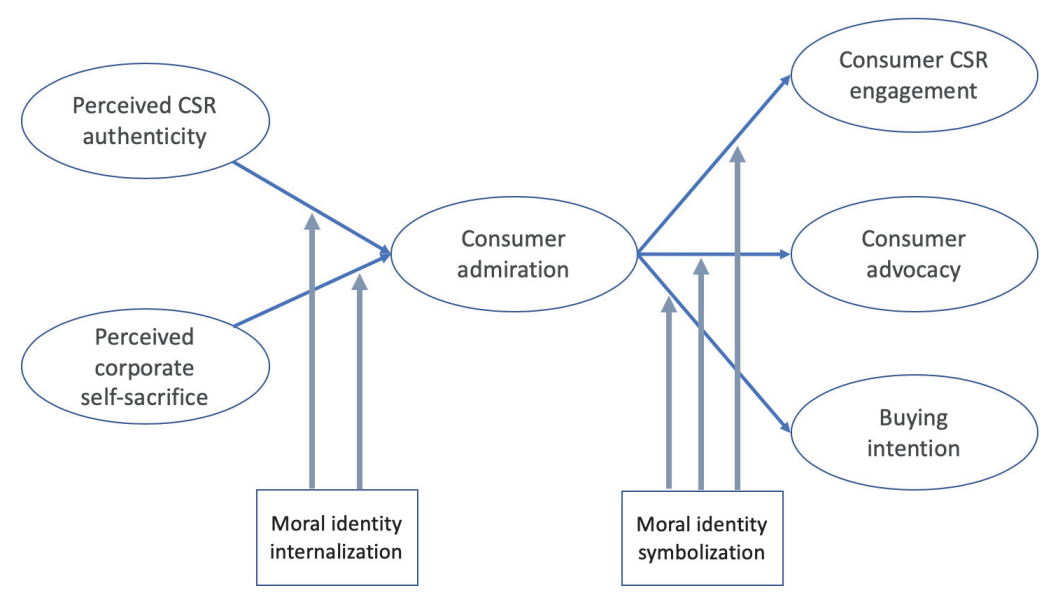

32 ASIA MARKETING JOURNAL Vol. 22 No. 02 July 2020 
the proposed hypotheses above is shown in $\langle$ Figure 1〉.

\section{Methodology}

\subsection{Sample and Procedure}

We collected Korean and international sample data via survey using individually completed questionnaires. Korean data was acquired from a national university in Seoul, South Korea, by distributing Google survey links to staff members, faculty, and students. Each participant received a coffee coupon of 5,000 won as a reward. The international data was gathered from Amazon Mechanical Turk and each respondent was given $\$ 2$ as a reward. The total number of respondents was 561, composed of 263 from the Korean sample and 298 from the international sample. The total male and female ratio is $49.2 \%: 50.8 \%$, composed of $94(35.7 \%): 169(64.3 \%)$ from the Korean sample and 182(61.1\%) : 116(38.9\%) from the international sample. The ratio of ethnicity of international sample was 38.9\% Caucasian, 51.7\% Asian, 3.4\% Hispanic, and 6.0\% African or other from various continents. The age distribution of aggregate sample was $38.3 \%$ in 20 's, $40.8 \%$ in $30^{\circ}$ s, $12.8 \%$ in 40 's, $5.8 \%$ in 50 's, and $2.3 \%$ in 60 's or older.

At the beginning of the questionnaire, respondents were asked to answer 'yes' or 'no' about their prior subjective knowledge of Patagonia and if they have ever purchased from Patagonia. If a respondent had ever purchased from Patagonia, he or she was asked to evaluate their overall customer satisfaction (CS). $76.2 \%$ of the international sample and $52.9 \%$ of the Korean sample said 'yes' to the question of prior subjective knowledge about Patagonia. $70.5 \%$ of the international sample and $19.0 \%$ of the Korean sample had ever purchased from Patagonia. Next, the respondents were provided a one-page summary of Patagonia's CSR initiatives and also the details of its "Worn Wear Program' with a URL (see Appendix). As Kim \& Ferguson (2014) emphasized the importance of web site to effective CSR communication, Patagonia utilizes their web site to inform the visitors about their missions and enduring efforts for environmental cause. Joo et al. (2019) inserted the CSR web site of their study into the survey. Likewise, we administered our survey by inserting the URL of the web site of 'Worn Wear Program' to redirect any participants who wanted more information. All the respondents were instructed to take time reading and adequately understanding the summary report before they started to fill in the questionnaire.

\subsection{Measurement}

Multiple measurement items were selected 
for each construct based on previous literature. We referred to measurement items used in the existing literature to specify the constructs to be measured in our study. We modified the measurement items to adapt for the specific Patagonia environmental CSR campaign, their 'Worn Wear Program.'

The measures of 'perceived CSR authenticity' were measured using a twenty-one-item scale developed by Joo et al. (2019). They developed seven sub-dimensions of perceived CSR authenticity with three measurement items per dimension. The sub-dimensions are 'community link', 'reliability', 'commitment', 'congruence', 'benevolence', 'transparency', and 'broad impact.' Some examples follow: "Patagonia provides a great deal of support for environment protection through the "Worn Wear Program” (Commitment), "Patagonia and its 'Worn Wear Program' fit together well” (Congruence), "Patagonia's 'Worn Wear Program' accomplishes what it says it will accomplish" (Reliability). Participants rated each item on the 9-point scale $(1=$ not at all, $9=$ quite a lot).

Self-sacrifice indicates a person's willingness "to suffer the loss of types of things to maintain personal beliefs and values" (Yorges, Weiss, \& Strickland, 1999, p. 428). We used a six-item measure to evaluate "perceived corporate self-sacrifice, adapted from Bélanger et al. (2014). For example: "I can reliably count on Patagonia to help and support the environmentally responsible activities such as the 'Worn Wear
Program,' even if it is at costs to the company", and "Patagonia would be prepared to endure economic hindrance if it meant defending the important cause of the 'Worn Wear Program' ". The same 9 -point scale was used $(1=$ not at all, $9=$ quite a lot).

Consumer admiration for the firm was measured using a four-item scale developed by Algoe \& Haidt (2009). For example: “As I get to know more, 'I admire Patagonia', "As I get to know more, 'I am inspired by Patagonia'". Responses were rated on the 9 -point scale $(1=$ not at all, $9=$ quite a lot $)$.

Consumer CSR engagement measures were adapted from $\mathrm{He}$ et al. (2014) and originally developed by Rich, Lepine, \& Crawford (2010). The original eleven-item scale was designed to quantify employee engagement in three subdimensions: four items for physical, three items for emotional, and four items for cognitive engagement. We modified the measures from a consumer's viewpoint. A nine-item scale consisting of three items for each sub-dimension was used. For example: "I would be willing to participate in Patagonia's 'Worn Wear Program" " (Physical engagement). "I would be excited about participation in Patagonia's 'Worn wear Program" (Emotional engagement). "During participation in Patagonia's 'Worn Wear Program', I would focus a great deal of attention on its environmental cause" (Cognitive engagement). All the items were measured using the 9-point scale $(1=$ not at all, $9=$ quite a lot $)$. 
Advocacy was assessed using a four-item measure adapted from Joo et al. (2019) on the conceptualization of Du, Bhattacharya, \& Sen (2007, 2010). Du et al. (2010) argued that consumers could become "company/brand ambassadors and champions who engage in advocacy behavior (e.g., positive word-of-mouth, willingness to pay a price premium, and resilience to negative company news)" (p. 9). We adjusted the measures to our Patagonia case. For example: "I would speak favorably of Patagonia's 'Worn Wear Program' to others." "I would stand by Patagonia even amidst a negative news release about the company." Responses were rated on the 9-point scale $(1=$ not at all, $9=$ quite a lot $)$.

Buying intention was assessed using a threeitem measure. The items were designed to evaluate the respondent's relative intention as well as general intention to purchase Patagonia. For example: "I'm willing to pay more money to buy Patagonia's clothes compared to those of other similar brands." "I plan to purchase Patagonia's clothes when I need some outdoor clothes." Responses were again on the 9-point scale $(1=$ not at all, $9=$ quite a lot $)$.

Moral identity was measured using the techniques detailed by Aquino \& Reed (2002). The respondents were instructed to imagine how a caring, compassionate, fair, friendly, generous, helpful, hardworking, honest and kind person would think, feel, and act. For example: "It would make me feel good to be a person who has these characteristics" (e.g., internalization). "I often wear clothes that identify me as having these characteristics" (e.g., symbolization). Seven items for internalization and six items for symbolization were completed by respondents on a 9 -point scale $(1=$ not at all, $9=$ quite a lot). Reversed scales were recomputed and all items were averaged to form two subscales for moderation analyses. Cronbach reliability $(\alpha)$ of the internalization was .64 and that of the internalization was .94, which was consistent with Winterich et al.'s (2013).

Personal connection with the environmental cause, personal prior experience history of participation in environmental/social movements, and prior purchase experience at Patagonia were measured for the use as control variables. Personal connection was quantified using threeitem measure adapted from Joo et al. (2019). For example: "I feel a personal connection to programs designed to fight for environment." Past experience with CSR was measured using two items. For example: "I have participated in activities related to environmental cause." The 9 -point scale was used $(1=$ not at all, $9=$ quite a lot). Responses to prior purchase were collected with either of 'yes' or 'no' answer.

For structural equation modeling, twenty-one items for 'perceived CSR authenticity' were aggregated into seven sub-dimensions. Additionally, nine items for 'consumer CSR engagement' were aggregated into three dimensions of physical, 
emotional, and cognitive engagement using the parcel approach recommended by Little (Little, Cunningham, Shahar, \& Widaman, 2002).

\section{Results}

\subsection{Evaluation of the Measurement Scales}

Before proceeding to testing the conceptual model, the psychometric properties of the scales were tested to ensure that the model properly fit the data. For this purpose, the reliability and validity tests of the measurement model were conducted (Churchill, 1979). The properties of all the items were identified as reflective measures on their respective construct and evaluated through a comprehensive confirmatory factor analysis (CFA) using AMOS 21.0. 〈Table 1〉 shows the scale statistics of all factors, including the Cronbach alpha $(\alpha)$ reliability, standard deviations, intercorrelations, and shared variances. The summary of the measurement results and diagnostic statistics appear in $\langle$ Table 2$\rangle$, where the parameter estimates, $t$-values, composite reliability, and average variances extracted (AVE) are presented.

The overall measurement model fit indices

$\langle$ Table 1〉 Scale statistics

\begin{tabular}{|c|c|c|c|c|c|c|}
\hline Variables & $\begin{array}{l}\text { Perceived } \\
\text { CSR } \\
\text { authenticity }\end{array}$ & $\begin{array}{c}\text { Perceived } \\
\text { corporate } \\
\text { self-sacrifice }\end{array}$ & $\begin{array}{l}\text { Consumer } \\
\text { admiration }\end{array}$ & $\begin{array}{c}\text { Consumer } \\
\text { CSR } \\
\text { engagement }\end{array}$ & $\begin{array}{l}\text { Consumer } \\
\text { advocacy }\end{array}$ & $\begin{array}{l}\text { Buying } \\
\text { intention }\end{array}$ \\
\hline $\begin{array}{c}\text { Perceived } \\
\text { CSR } \\
\text { authenticity }\end{array}$ & .94 & .53 & .65 & .56 & .52 & .34 \\
\hline $\begin{array}{c}\text { Perceived } \\
\text { corporate } \\
\text { self-sacrifice }\end{array}$ & $\begin{array}{l}.73 \\
(.02)\end{array}$ & .95 & .53 & .41 & .45 & .35 \\
\hline $\begin{array}{l}\text { Consumer } \\
\text { admiration }\end{array}$ & $\begin{array}{l}.81 \\
(.01) \\
\end{array}$ & $\begin{array}{l}.73 \\
(.02) \\
\end{array}$ & .92 & .60 & .62 & .41 \\
\hline $\begin{array}{l}\text { Consumer } \\
\text { CSR } \\
\text { engagement }\end{array}$ & $\begin{array}{l}.75 \\
(.02)\end{array}$ & $\begin{array}{c}.64 \\
(.03)\end{array}$ & $\begin{array}{l}.77 \\
(.02)\end{array}$ & .92 & .64 & .47 \\
\hline $\begin{array}{l}\text { Consumer } \\
\text { advocacy }\end{array}$ & $\begin{array}{l}.72 \\
(.02) \\
\end{array}$ & $\begin{array}{c}.67 \\
(.03) \\
\end{array}$ & $\begin{array}{l}.78 \\
(.02) \\
\end{array}$ & $\begin{array}{l}.80 \\
(.02) \\
\end{array}$ & .87 & .56 \\
\hline $\begin{array}{l}\text { Buying } \\
\text { intention }\end{array}$ & $\begin{array}{l}.58 \\
(.03)\end{array}$ & $\begin{array}{l}.59 \\
(.03)\end{array}$ & $\begin{array}{l}.64 \\
(.03)\end{array}$ & $\begin{array}{l}.68 \\
(.02)\end{array}$ & $\begin{array}{l}.75 \\
(.02)\end{array}$ & .91 \\
\hline
\end{tabular}

〈Notes〉 Intercorrelations are presented in the lower triangle of the matrix. Standard errors appear in parentheses. The content reliability (Cronbach-alpha (a)) of each scale is bolded and on the diagonal. Squared correlations are given in the upper triangle of the matrix. 
〈Table 2〉 Summary of Measurement Results

\begin{tabular}{|c|c|c|c|c|c|c|}
\hline Variables & $\begin{array}{l}\text { Measurement } \\
\text { items }\end{array}$ & Mean (SD) & Lambda*$^{*}(\lambda)$ & t-value & $\begin{array}{l}\text { Composite } \\
\text { reliability }\end{array}$ & AVE \\
\hline \multirow{7}{*}{$\begin{array}{c}\text { Perceived CSR } \\
\text { authenticity }\end{array}$} & PCA1 & $6.92(1.61)$ & .89 & 27.05 & \multirow{7}{*}{.95} & \multirow{7}{*}{.73} \\
\hline & PCA2 & $6.77(1.48)$ & .82 & 23.66 & & \\
\hline & PCA 3 & $7.13(1.47)$ & .84 & 24.33 & & \\
\hline & PCA 4 & $6.99(1.52)$ & .79 & 22.52 & & \\
\hline & PCA 5 & $6.89(1.49)$ & .88 & 26.18 & & \\
\hline & PCA 6 & $6.57(1.46)$ & .88 & 26.02 & & \\
\hline & PCA 7 & $7.00(1.48)$ & .78 & 21.82 & & \\
\hline \multirow{6}{*}{$\begin{array}{c}\text { Perceived } \\
\text { corporate } \\
\text { self-sacrifice }\end{array}$} & PCSS1 & $6.41(1.84)$ & .84 & 22.40 & \multirow{6}{*}{.94} & \multirow{6}{*}{.74} \\
\hline & PCSS2 & $6.38(1.86)$ & .87 & 25.85 & & \\
\hline & PCSS3 & $6.25(1.84)$ & .89 & 26.62 & & \\
\hline & PCSS4 & $6.44(1.81)$ & .89 & 26.24 & & \\
\hline & PCSS5 & $6.18(1.93)$ & .87 & 26.01 & & \\
\hline & PCSS6 & $6.09(1.94)$ & .80 & 22.58 & & \\
\hline \multirow{4}{*}{$\begin{array}{l}\text { Consumer } \\
\text { admiration }\end{array}$} & CAM1 & $6.96(1.76)$ & .90 & 27.16 & \multirow{4}{*}{.92} & \multirow{4}{*}{.73} \\
\hline & CAM2 & $6.80(1.81)$ & .87 & 25.71 & & \\
\hline & CAM3 & $6.51(1.93)$ & 84 & 24.12 & & \\
\hline & CAM4 & $6.32(2.03)$ & .80 & 22.56 & & \\
\hline \multirow{3}{*}{$\begin{array}{l}\text { Consumer } \\
\text { CSR } \\
\text { engagement }\end{array}$} & CSE1 & $6.67(1.74)$ & .91 & 27.74 & \multirow{3}{*}{.96} & \multirow{3}{*}{.89} \\
\hline & CSE2 & $6.63(1.69)$ & .95 & 29.71 & & \\
\hline & CSE3 & $6.67(1.83)$ & .96 & 26.44 & & \\
\hline \multirow{4}{*}{$\begin{array}{l}\text { Consumer } \\
\text { advocacy }\end{array}$} & CAV1 & $6.88(1.75)$ & .85 & 24.77 & \multirow{4}{*}{.89} & \multirow{4}{*}{.68} \\
\hline & CAV2 & $6.76(1.82)$ & .89 & 26.35 & & \\
\hline & CAV3 & $6.90(1.73)$ & .89 & 26.49 & & \\
\hline & CAV4 & $5.69(2.18)$ & .65 & 16.73 & & \\
\hline \multirow{3}{*}{$\begin{array}{l}\text { Buying } \\
\text { intention }\end{array}$} & BI1 & $5.85(2.06)$ & .90 & 26.75 & \multirow{3}{*}{.91} & \multirow{3}{*}{.77} \\
\hline & $\mathrm{BI} 2$ & $5.78(2.10)$ & .90 & 26.97 & & \\
\hline & $\mathrm{BI} 3$ & $6.18(2.00)$ & .83 & 23.61 & & \\
\hline
\end{tabular}

$\langle$ Notes〉*Standardized parameter estimates. Standard Errors are in parentheses.

indicate that the CFA model fits the data well (Jöreskog \& Sörbom, 1989) : $x^{2}$ (293) $=863.21$ $(\mathrm{p}=.00), x^{2} / \mathrm{df}=2.95, \mathrm{CFI}=.96, \mathrm{NNFI}=$ $.96, \mathrm{SRMR}=.04$, RMSEA $=.06$. To test convergent validity, we examined the Lambda $(\lambda)$ loadings with $t$-value and the AVE (Fornell \& Larcker, 1981). The lowest Cronbach alpha $(\alpha)$ coefficient was 0.87 for "consumer advocacy' and the Cronbach alpha $(\alpha)$ of all other constructs were over 0.90 . The composite 
reliability, known as a more rigorous reliability indicator, ranged from 89 to .96. The $t$-values of the Lambda $(\lambda)$ loadings of each measure were significant $(p=.01)$, and the AVE for each construct ranged from .68 to .89. Thus, we were able to discern that the measurement model had an adequate convergent validity (Fornell \& Larcker, 1981).

Discriminant validity was also tested using the criteria suggested by Fornell \& Larcker (1981). We found that the AVE of each scale in 〈Table 2〉 was greater than the shared variance between the construct and all other variables in 〈Table 1〉. These results indicate that the measurement model achieved high discriminant validity. Both 〈Table 1〉 and $\langle$ Table 2〉 demonstrate that each latent variable has good measurement properties and is distinct from the other latent variables (Anderson \& Gerbing, 1988; Fornell \& Larcker, 1981). In other words, the measurement model fits the data well and demonstrates adequate reliability, good convergence and acceptable discriminant validity.

\subsection{Testing the Structural Equation Model}

Since the validity tests of the measurement scales yielded acceptable results, the relationships of the proposed constructs in 〈Figure 1〉 were estimated by using structural equation modeling (SEM) analysis. We used aggregated sample data to test the research model since the purpose of this study is to examine the general causal relationships among proposed constructs. The simple t-test differences between Korean and international sample will be discussed in the light of practical implications. The fit indices show that the proposed model is reasonable and acceptable: $x^{2}=860.98(299)(\mathrm{p}=.00)$, $x^{2} / \mathrm{df}=2.88, \mathrm{CFI}=.96, \mathrm{NNFI}=.96, \mathrm{SRMR}=$ .09 , and RMSEA $=.06$. All the hypothesized paths were significant at $p=.001$ and the explanatory power of the model for individual constructs was examined using the $R^{2}$ for each dependent construct. As shown in 〈Figure 2〉, 'Perceived CSR authenticity' and 'Perceived corporate self-sacrifice' explained $83 \%$ of the variance of consumer admiration, 68\% of the variance of consumer CSR engagement, 78\% of the variance of consumer advocacy, and $46.8 \%$ of buying intention. Taken together, we conclude that the hypothesized causal relationships among constructs are supported. Accordingly, Hypotheses 1, 2, 3, 4, and 5 were supported.

\subsection{Testing the Moderation Effect}

To test the moderation effect of moral identity internalization (MI_in) and Moral identity symbolization (MI_sy), we applied model \#28 of PROCESS macro (Hayes, 2013). We hypothesized that MI_in (Moderator W) would moderate the relationship of perceived CSR authenticity $(\mathrm{X})$ and consumer admiration (M) 
〈Figure 2〉 The Results of SEM with Estimates of Path Coefficients

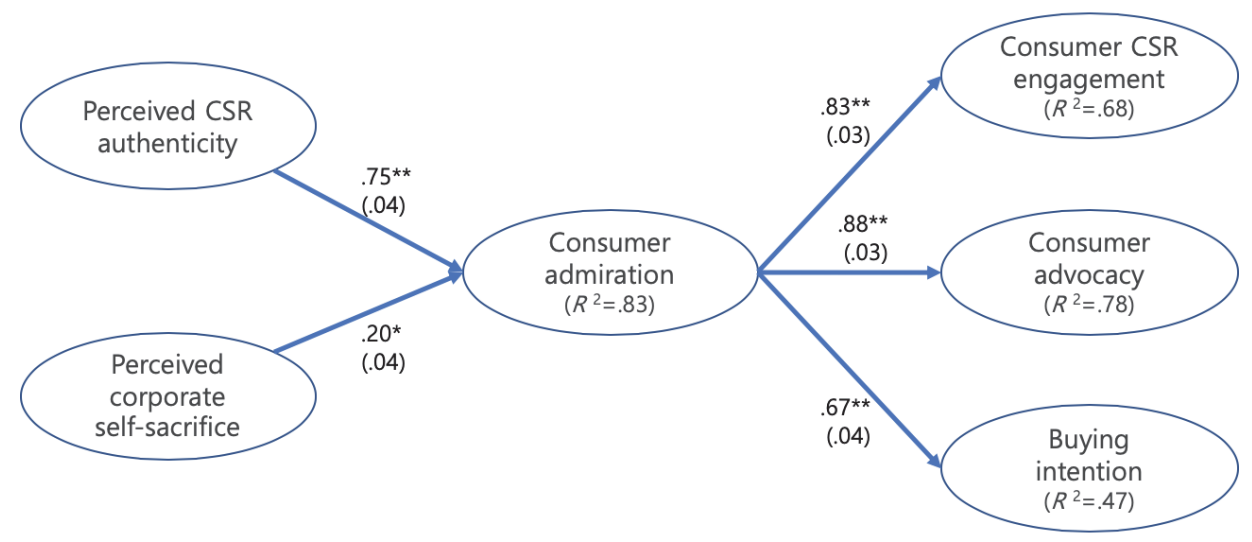

〈Notes〉 Standard errors appear in parentheses. ${ }^{*} p<.001,{ }^{* *} p<.0001$.

and also moderate the relationship of perceived corporate self-sacrifice $(\mathrm{X})$ and consumer admiration (M). MI_sy (Moderator V) was hypothesized to interact with consumer admiration (M) in influencing outcome constructs which were consumer CSR engagement, advocacy, and buying intention. Also, we hypothesized that MI_sy (V) would influence consumer CSR engagement, advocacy, and buying intention by interacting with perceived CSR authenticity and perceived corporate self-sacrifice. We produced the results with 5,000 resampling bootstrapping with a 95\% confidence interval. The results are shown in 〈Table 3$\rangle$, 〈Table $4 \mathrm{a}\rangle$, and $\langle$ Table $4 \mathrm{~b}\rangle$. The results were drawn after three control variables were included: personal connection to environment (Joo et al., 2019); personal prior cause-related participation experience; prior purchase experience with Patagonia (dummy coded to '0' for no or ' 1 ' for yes).

\subsubsection{Moderation Effect on Admiration}

As shown in 〈Table 3〉, there was found to be no significant moderation effect of MI_in on both the path from perceived CSR authenticity to consumer admiration and the path from perceived corporate self-sacrifice to consumer admiration. Instead, we discovered the direct effect of MI_in on consumer admiration in Model_2. Thus, we can conclude there is no interaction effect of moral identity internalization with perceived CSR authenticity nor with perceived corporate self-sacrifice in forming consumer admiration. According to the results, Hypotheses 6A and 6B were not supported.

\subsubsection{Moderation Effect on Engagement and Advocacy}

We first conducted testing the moderation effects of MI_sy on CSR engagement and 
〈Table 3〉 The Results of Moderation Analysis of Ml_internalization

\begin{tabular}{|c|c|c|c|}
\hline \multirow{2}{*}{\multicolumn{2}{|c|}{ Model }} & Outcome Variable & \multirow{2}{*}{ Model Summary } \\
\hline & & Customer Admiration & \\
\hline \multirow{3}{*}{ Model__1 } & P.CSR authenticity & $.76^{* *}$ & \multirow{3}{*}{$R^{2}=.687, F(6,554)=202.65^{* *}$} \\
\hline & MI_in & n.s. & \\
\hline & Int_MI_in $\mathrm{x}$ authenticity & n.s. & \\
\hline \multirow{3}{*}{ Model__2 } & P.C.Self-sacrifice & $.64^{* *}$ & \multirow{3}{*}{$R^{2}=.626, F(6,554)=154.38 * *$} \\
\hline & MI-in & $.34^{* *}$ & \\
\hline & Int_MI_in $\mathrm{x}$ sacrifice & n.s. & \\
\hline
\end{tabular}

〈Notes〉Int: Interaction, MI_in: Moral identity internalization, P.CSR authenticity: Perceived CSR authenticity, P.C.Self-sacrifice: Perceived corporate self-sacrifice. ${ }^{* *} p<.0001$.

〈Table 4a〉 The Results of Moderation Analysis of MI_symbolization

\begin{tabular}{|c|c|c|c|}
\hline \multirow{2}{*}{\multicolumn{2}{|c|}{ Model }} & \multicolumn{2}{|c|}{ Outcome Variable } \\
\hline & & (A) Consumer engagement & (B) Consumer advocacy \\
\hline \multirow{6}{*}{ Model__3 } & P.CSR authenticity & n.s. & n.s. \\
\hline & Consumer admiration & $.59 * * * *$ & $.52 * * * *$ \\
\hline & MI_sy & n.s. & n.s. \\
\hline & Int_MI_sy $\mathrm{x}$ authenticity & $.05^{* *}$ & $.05^{* *}$ \\
\hline & Int_MI_sy $\mathrm{x}$ admiration & $-.03^{*}$ & $-.03^{* *}$ \\
\hline & Model summary & $R^{2}=.68, \mathrm{~F}(8,552)=145.18^{* * * * *}$ & $R^{2}=.72, \mathrm{~F}(8,552)=179.09^{* * * * *}$ \\
\hline \multirow{6}{*}{ Model_4 } & P.C.Self-sacrifice & n.s. & n.s. \\
\hline & Consumer admiration & $.72^{* * *}$ & $.49^{* * * * *}$ \\
\hline & MI_sy & n.s. & n.s. \\
\hline & $\begin{array}{l}\text { Int_MI_sy x } \\
\text { P.C.Self-sacrifice }\end{array}$ & $.05^{* * * * *}$ & n.s. \\
\hline & Int_MI_sy $\mathrm{x}$ admiration & $-.04^{* *}$ & n.s. \\
\hline & Model summary & $R^{2}=.67, F(8,552)=140.16^{* * * *}$ & $R^{2}=.72, F(8,552)=179.33^{* * * * *}$ \\
\hline
\end{tabular}

〈Notes〉Int: Interaction, MI_sy: Moral identity symbolization, P.CSR authenticity: Perceived CSR authenticity, P.C.Self-sacrifice: Perceived corporate self-sacrifice. ${ }^{*} p<.05,{ }^{* *} p<.01,{ }^{* * *} p<.001^{* * * *} p<.0001$.

advocacy. As shown in $\langle$ Table $4 \mathrm{a}\rangle$, we found a significant positive interaction effect of MI_sy with perceived CSR authenticity on consumer CSR engagement in Model_3(A) and on consumer advocacy Model_3(B). Also, the results show a significant negative interaction effect of MI_sy with consumer admiration in the formation process of consumer CSR engagement in Model__ 3(A) and consumer advocacy in Model_3(B). Likewise, there was 
found to be a significant positive interaction effect of MI_sy with perceived corporate self-sacrifice on consumer CSR engagement and a significant negative interaction effect of MI_sy with consumer admiration on consumer CSR engagement in Model_4(A). There were no significant interaction effects of MI_sy with perceived corporate self-sacrifice nor with consumer admiration on consumer advocacy, as shown in Model_4(B). According to the results, Hypothesis $7 \mathrm{Aa}, 7 \mathrm{Ab}$ and $7 \mathrm{Ba}$ were supported and Hypothesis 7Bb was not supported.

Seeking in-depth implications of moderation effects which were proved significant, we examined the interaction patterns by speculating how the simple slope of consumer CSR engagement and advocacy changes as perceived CSR authenticity, self-sacrifice, and consumer admiration increases respectively according to the level of respondents' MI_sy (-1SD, Mean, +1SD; Aiken, West, \& Reno, 1991; Winterich et al., 2013). The slopes are visualized in 〈Figure 3〉, $\langle$ Figure 4$\rangle$, and $\langle$ Figure 5$\rangle$.

The graphs in 〈Figure 3$\rangle$ and $\langle$ Figure 4$\rangle$ show the tendency for higher MI_sy to have a synergistic interaction impact with consumers' perceived CSR authenticity in forming engaging intention in CSR campaigns, and also in forming advocation intention for the company. Also, the graphs in 〈Figure 5〉 show a tendency for higher MI_sy to have a synergistic interaction impact with consumers' perceived corporate self-sacrifice in forming engaging intention in CSR campaigns.

On the other hand, higher MI_sy has a depreciating interaction impact as consumers feel higher admiration for a company when they are deciding future intentions to engage

〈Figure 3〉 The Interaction Effect of Model 3(A)
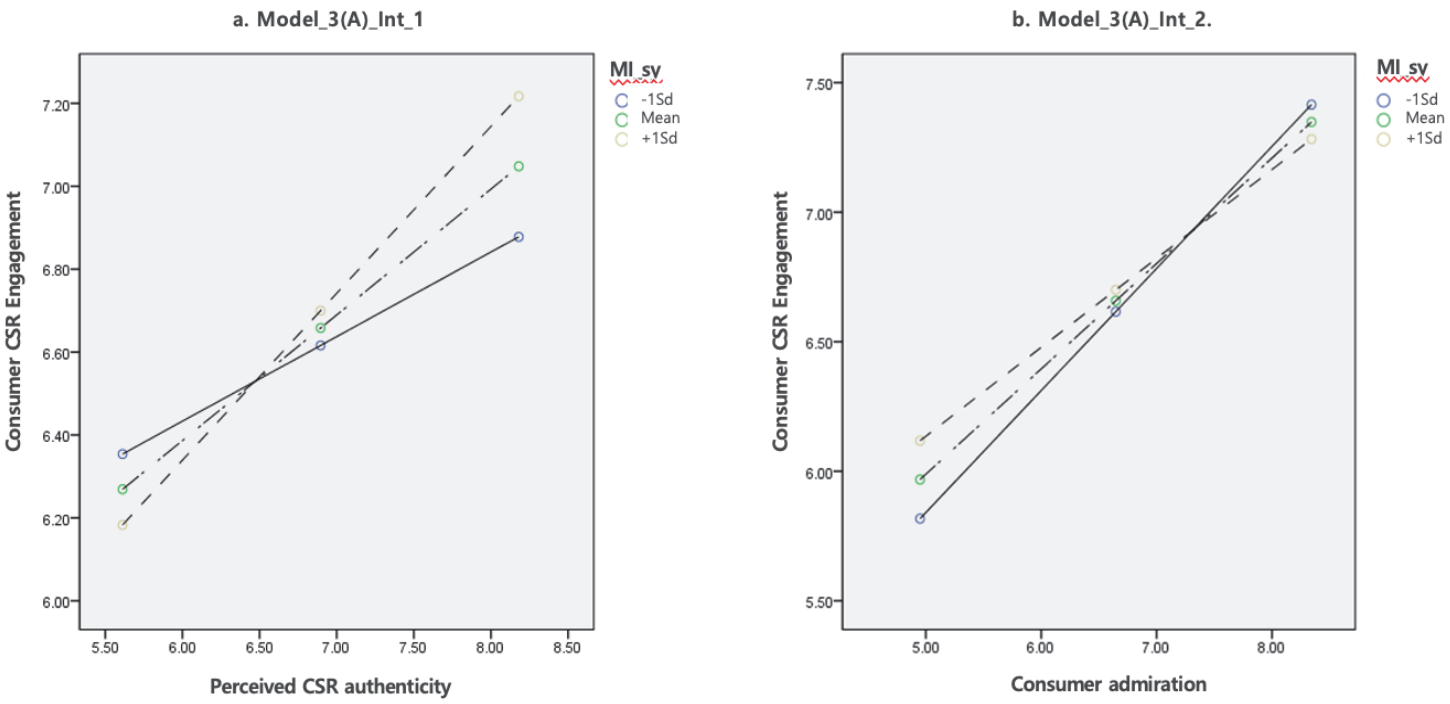

Wear Your Heart on Your Sleeve: Exploring Moral Identity as a Moderator Across CSR Authenticity, Consumer Admiration, and Engágement in the Fashion Industry 41 
〈Figure 4〉 The Interaction Effect of Model 3(B)
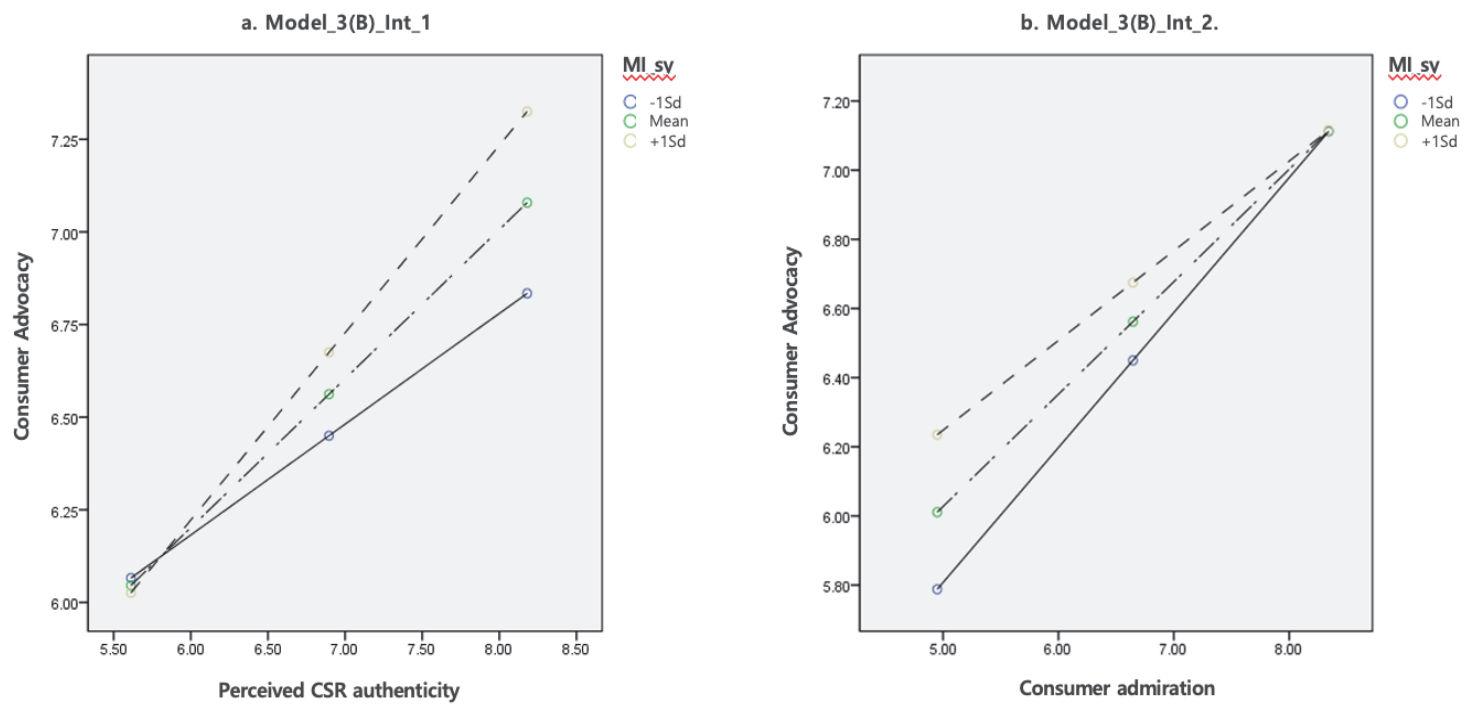

〈Figure 5〉 The Interaction Effect of Model 4(A)

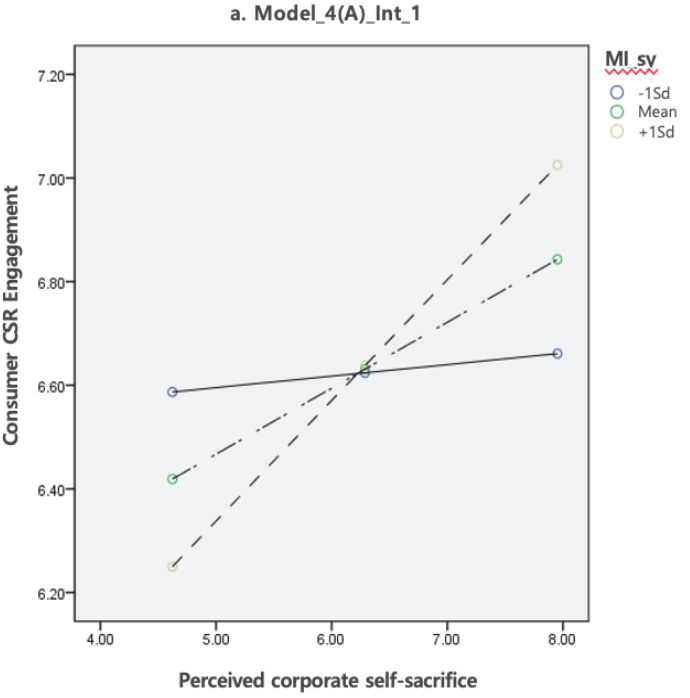

and advocate. The result indicates that there is less contribution of MI_sy in motivating a person to display one's moral characteristics to others as consumer admiration increases. This implies that consumer admiration is more of a b. Model_4(A)_Int_2.

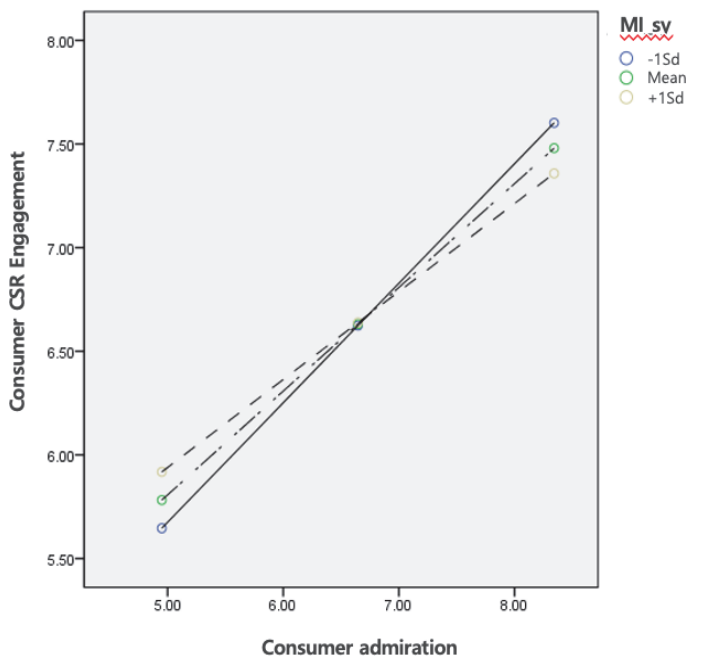

true respect for a company; therefore, as a customer feels higher admiration for the company, the consumer should be willing to engage in its CSR campaign and advocate with no assistance of symbolizing motivation. 
However, the moderation effect of MI_sy becomes more impactful when one's admiration is less cultivated.

\subsubsection{Moderation Effect on Buying Intention}

To test the moderation effect of MI_sy in the formation process of buying intention, we used both an aggregate sample $(n=561)$ and a partial sample of customers with prior purchase experience at Patagonia $(n=206)$ for the comparison between general consumers vs. existing customers. For the aggregate sample, all three control variables were included as in the earlier analyses. However, for the group of existing customers, we put overall customer satisfaction (CS) instead of prior purchase. To report the results of moderation effect on buying intention, we also presented the estimates of two control variables in the tables below because we thought customers versus non-customers might be differentiated from each other in deciding future purchase with regard to the experiences of prior purchase and the level of overall CS.

As shown in $\langle$ Table $4 \mathrm{~b}\rangle$, we found no significant interaction effect of MI_sy in Model_5(A), Model_5(B), Model_6(A), and Model_6(B). Prior purchase experience with Patagonia has a significant positive impact on buying intention among the aggregate sample. This implies that once a consumer made a purchase from
Patagonia, the consumer will have a high tendency to repurchase. In other words, the customer base of Patagonia is mainly consisted of repeat customers. Interestingly, existing customers who have ever made a purchase at Patagonia tend to be positively affected by their intensity of MI_sy in forming repurchase intention as shown in Model_5(B) and Model 6(B). Among those consumers, felt admiration is still a major significant factor even when overall CS is controlled in predicting buying intention. It is noteworthy that the impact of admiration on buying intention is bigger $(.38, .43)$ than overall CS $(.16, .19)$ among existing customers. Another interesting finding is that the general consumers (the aggregate sample) decided their future purchase not by moral identity symbolization but by admiration for the company since symbolization motivation was not significant in predicting future purchase among general consumers.

We conclude that there is no moderation effect of MI_sy with admiration on buying intention; however, there is a direct positive effect of MI_sy in both general and existing customers of Patagonia. It is noteworthy that the results indicate that existing Patagonia customers are highly interested in presenting their moral characteristics to others by purchasing or wearing the brand, which means the customers are already activists to vote for the cause in spending their money in consumption. According to the results, all the hypothesized moderation 
〈Table 4b〉 The Results of Moderation Analysis of Ml_symbolization

\begin{tabular}{|c|c|c|c|}
\hline \multirow{2}{*}{\multicolumn{2}{|c|}{ Model }} & \multicolumn{2}{|c|}{ Outcome Variable } \\
\hline & & (A) Buying intention $(\mathrm{n}=561)$ & (B) Buying intention $(\mathrm{n}=260)$ \\
\hline \multirow{8}{*}{ Model__5 } & P.CSR authenticity & $\begin{array}{l}\text { n.s. } \\
\end{array}$ & n.s. \\
\hline & Consumer admiration & $.43^{* * *}$ & $.38 *$ \\
\hline & MI_sy & n.s. & $.56^{* *}$ \\
\hline & Int_1_MI_sy x authenticity & n.s. & n.s. \\
\hline & Int_2_MI_sy $\mathrm{x}$ admiration & n.s. & n.s. \\
\hline & Prior purchase $(\mathrm{CV})$ & $.60^{* * * *}$ & - \\
\hline & Overall CS (CV) & - & $.16^{* *}$ \\
\hline & Model summary & $R^{2}=.60, F(8,552)=103.69 * * *$ & $R^{2}=.65, \mathrm{~F}(8,251)=58.53^{* * *}$ \\
\hline \multirow{8}{*}{ Model__6 } & P.C.Self-sacrifice & n.s. & n.s. \\
\hline & Consumer admiration & $.74^{* * *}$ & $.43^{*}$ \\
\hline & MI_sy & n.s. & $.47^{* * * *}$ \\
\hline & Int_MI_sy x P.C. Self-sacrifice & n.s. & n.s. \\
\hline & Int_2_MI_sy $\mathrm{x}$ admiration & n.s. & n.s. \\
\hline & Prior purchase $(\mathrm{CV})$ & $.62 * * *$ & - \\
\hline & Overall CS (CV) & - & $.19 * * *$ \\
\hline & Model summary & $R^{2}=.60, F(8,552)=104.14^{* * *}$ & $R^{2}=.67, \mathrm{~F}(8,251)=64.52^{* * *}$ \\
\hline
\end{tabular}

〈Notes〉Int: Interaction, MI_sy: Moral identity symbolization, P.CSR authenticity: Perceived CSR authenticity, P.C.Self-sacrifice: Perceived corporate self-sacrifice. CV: control variable. ${ }^{*} p<.01,{ }^{* *} p<.001,{ }^{* * *} p<.0001$.

effects of MI_sy on buying intention, which were Hypothesis 7Ac, 7Bc and 8c, turned out not being supported.

According to the results of moderation effects tests, Hypotheses 7A, 7B, and 8 were partially supported. In Hypothesis 7A, consumer moral identity symbolization has a positive interaction effect with perceived CSR authenticity on consumer CSR engagement (Hypothesis 7Aa) and advocacy (Hypothesis 7Ab), but not on buying intention (Hypothesis 7Ac). In Hypothesis $7 \mathrm{~B}$, consumer moral identity symbolization has a positive interaction effect with perceived corporate self-sacrifice on consumer CSR engagement (Hypothesis $7 \mathrm{Ba}$ ), but not on advocacy (Hypothesis 7Bb) or buying intention (Hypothesis 7Bc). In Hypothesis 8, consumer moral identity symbolization has a negative interaction effect with consumer admiration on consumer CSR engagement (Hypothesis 8a) and advocacy (Hypothesis 8b), but not on buying intention (Hypothesis 8c).

\section{Discussion}

\subsection{Conclusion}

Though CSR campaigns are becoming 
increasingly considered and often scrutinized (Pirsch, Gupta, \& Grau, 2007), without effective measures for successful CSR in the consumer domain, efforts will likely fail. Our study explores the mechanism of consumer admiration as a motivational and emotional driving factor towards active engagement in, and genuine advocacy for, CSR programs.

In investigating the determinants and outcome variables of consumer admiration, we looked to Patagonia as a company that has successfully endeavored to encourage customer engagement with CSR initiatives. Using the company, we investigated how to cultivate admiration by adopting perceptions of authenticity and selfsacrifice, and the structural equation analysis confirmed the proposed causal relationships across admiration with its antecedents and outcomes. Our study can provide a lesson regarding the initiation of CSR programs; they should cultivate genuine admiration by sustainably representing authenticity. In the long run, consumer respect will trigger active partnerships and loyalty that will likely outweigh short-term adversity or profit dips, if properly cultivated.

Successful CSR focusing on development of consumer admiration can yield revenue, reputation and even partnerships with brand advocates. In this study, we specifically examined the asymmetric moderation effects of consumers' moral identity internalization versus symbolization in forming admiration versus behavioral intentions; the moderation analyses yielded results that suggested moral identity symbolization interacts both with perceived CSR authenticity and perceived corporate self-sacrifice positively in affecting behavioral intentions (CSR engagement and advocacy). In contrast, it interacts with consumer admiration negatively in affecting behavioral intentions. As suggested, moral identity symbolizing motive compensates the lack of admiration when consumers decide to engage or advocate. The more a consumer feels admiration, the less of a need there is to artificially supplant this symbolizing motive when deciding to engage and advocate.

\subsection{Theoretical Contributions}

Our work continues upon the foundation of past research on the dimensions of moral identity, as well as the interplay between individual identity, perceptions on corporate social responsibility and self-sacrifice, and degrees of admiration in consumer outlooks on corporations. In the past, previous research has analyzed the interrelationships between internalization and symbolization from unidimensional (Aquino et. al., 2009), additive, or two-dimensional conceptualizations (Winterich et. al., 2013) in an effort to evaluate and provide insight on effectors on the two with regard to the consumer; some studies have explored moral identity in the scope of specific concepts like prosocial behavior (see Winterich, 2013). However, we empirically show that CSR 
engagement and advocacy at-large can be intra-dimensionally moderated by moral identity in consumer metrics like admiration. In doing so, we demonstrate the importance of such metrics that are more directly tied to active engagement that highlights the consideration of consumers' expected outcomes in light of, and not distinct from, established perceptions of corporations.

Our research reflects the value of exploring dimensions of perceived CSR and moral identity in terms of interaction effects and joint effects. We propose the moderative capacity of an established and studied dimension of moral identity to the underlying effects of admiration; in doing so, we stress the importance of considering the moderative interaction effects of moral identity. As admiration increases, we find, there is less of a contribution from symbolization to motivate the presentation of moral characteristics.

This core idea of consumer admiration as an organic driving force in the chain of corporate social responsibility is our key contribution. In addition to highlighting how two distinct factors of moral identity should be considered when studying morally motivated consumer behavior, we highlight the theoretical value of understanding admiration as a multi-faceted factor that suggests alternative ways to look at the cultivation of such variables in a business context. Further, in adding the dimension of corporate self-sacrifice, we raise its need to be examined in the CSR context. While profit maximization has long been a standard insignia of success, the dimensions of how and what for, as we find, will likely become increasingly important to becoming admired and respected entities, and likely finding more sustained success. Demonstrated willingness from firms to risk sacrifice will not only be appreciated, but remarkably reciprocated by consumers.

Corporate social responsibility initiatives have a powerful role to play in the ever-developing business world as not just a fancy imagemaintenance strategy, but as a genuine and integral voice that projects to consumers whether a firm is, or will become, a true leader or not. Consumer admiration can act as an incredible emotional motivator (Aaker et al., 2012), and as our study's full mediation model was supported, our results imply the urgent need to investigate other mediators in predicting behaviors when using perceptions of CSR.

\subsection{Practical Implications}

Our findings are especially relevant to organizations looking to improve their approaches to becoming more in tune with the moral implications of their actions and the moral identities of their consumers. We present the key component of looking at adjusting corporate image and behavior for organic, genuine change rather than image maintenance under traditional conceptions of CSR. 
Worn fashion is observed publicly and inherently signals certain messages of self-image to many people. Our work is especially related to companies operating in the fashion industry, which is often characterized by rapid, marketwide consumer shifts in taste. In such a playing field, we find that prior purchase experience has a significant positive impact on buying intention among general consumers, and existing customers tend to be positively affected by their intensity of symbolization in forming buying intention. The symbolization motivation of one's moral self can directly influence purchasing, and it is important as a practical goal for modern companies, not solely limited to those in fashion.

Our findings indicate that consumer admiration is a full mediator, not a partial mediator, bridging from perceived CSR authenticity and corporate self-sacrifice to various behavioral intentions. Consumer admiration always plays into the equation as a reliable direct factor in predicting consumers' engagement, advocacy, and buying for the cause. Consumers' moral identity symbolization also serves as a direct predictor in future buying. However, this is only true for existing customers. For a more extensive range of consumers, including existing customers, cultivating consumer admiration gives a robust measure to the overall purposes of businesses in CSR contexts.

Organizations with well-established customer bases or metrics of high existing consumer admiration have the leeway to focus CSR campaigns on motivations other than moral identity symbolization. The positive direct effect of symbolization existed only in purchase behaviors of existing customers. The more an individual admires a certain company, there is less and less of a contribution of symbolization, implying that admiration is a steadfast representation of a consumer's respect for a company. As we write in the results, such customers will advocate and engage despite the adversities from no assisting motivational factors, suggesting that consumer-focused campaigns need not focus on such factors to increase moral identity symbolization as long as consumer bases are dedicated, or, at the very least, have prior purchasing experience.

Practically, these findings carry great gravity in an industry like that of fashion; we provide promising groundwork for redirecting corporate efforts from moral identity bolstering to consumer advocacy; effectively, we strengthen the argument for a transition from external focus to internal focus on the corporate-side of the market equation. It may be wise for similar organizations in fast-paced industries reliant on shifting consumer tastes to take closer looks at their consumers' past engagement and admiration to modify CSR campaigns.

In a sense, our model of approaching admiration as a substitute of moral identity internalization means that consumer behavior can be significantly motivated by their inner feelings and alliances. 
If consumers admire an organization highly already, they are less following after their signaling motivations, and their actions are not indicative of being "for show." Promoting consumers' moral identity symbolization motivation appears to be more effectively applied when the consumer bases of a company are in a vulnerable level of admiration. It may be wise for organizations to revise their campaigns accordingly in instances with high admiration in order to navigate the moderative effects of moral identity.

Our t-test results also provide important implications for global or international companies. As seen in $\langle$ Figure 6$\rangle$, there are statistically significant differences in MI_sy across each pair of ethnicity (between Korean and Asian $p=.00$ Asian and Caucasian $p=.03$, and Korean and Asian $p=.00$ ), suggesting that in adapting company initiatives for different areas should be carefully done according to racial demographics. A significant difference in MI symbolization of different race groups in one area a proposed CSR initiative targets may result in starkly differing consumer results because there will be different levels of moderation on admiration and consumer behavior. This will be important even in areas or continents companies may expect to be racially homogeneous, as seen in the difference between Korean and Asian MI_sy. We also find that subjective knowledge and prior purchase experience (S.Know_Y('yes')/N('no') and P.Purchase_

$\mathrm{Y}$ ('yes')/N('no')) yield significant difference among each pair of groups in symbolization at $p=.00$, but not in internalization. This suggests that global companies ought to especially take care with bridging subjective knowledge and purchasing experience and ethnic group makeups in the locations of proposed CSR campaigns in order to properly navigate the bridged relationship of admiration and behavior.

Finally, CSR could be effectively accomplished

\section{〈Figure 6〉 Mean Comparisons Across Groups (Additional)}

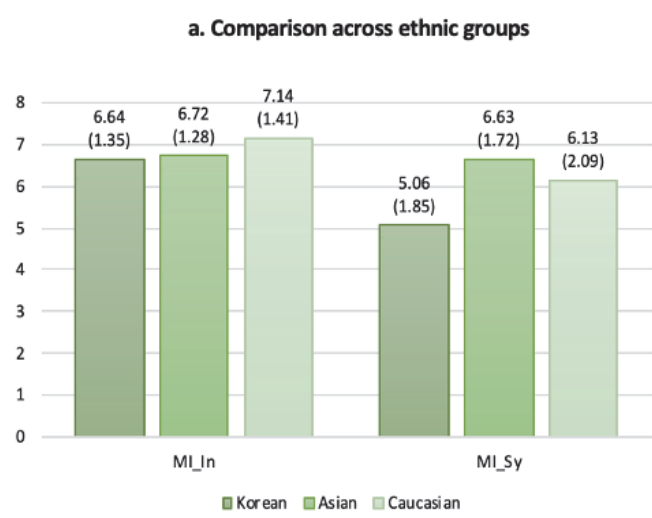

〈Note〉 The number is Mean (S.D) 
through a triangular companies-NGOs-consumers collaboration structure. Patagonia is one of example of such a collaboration. Past literature on the work of nongovernmental organizations offers a perspective of viewing slowly built cohesive movements as a robust basis for meaningful change, arguing that the more we avoid real political engagement and conscientization, the less connected we become to issues of politics, capitalism, and policy making (see Bendana, 2002 and Ramdas, 2011). To properly sow the seeds of change in capitalism for social good, Ramdas writes that "the proposition that business does not, after all, have all the answers, and that the social-benefit sector, particularly people's movements, have much knowledge and substance to share, would be an excellent starting-point for a dialogue" (Ramdas, 2011, p. 396). Literature from the world of NGOs offers another supporting premise for our argument that understanding social movements and CSR initiatives is crucial to proper operation. Further, this consumer-corporation dialogue is crucial to growing admiration for a company and the role of consumers as genuine activists for the cause.

\section{Limitations and Future Research}

Certain limitations should be recognized in interpreting the results of our research. First, our case summaries for Patagonia were required to be extensive enough to cover the core components of the company's CSR campaigns and concise enough to be unmotivating for respondents. Much of our questions, as detailed in the rest of the limitations section, have dimensions to improve on in future research, but in general, perfect answering of the questions would have required somewhat deeper understanding of the company, its campaign, and its motivations. Thus, a better replication of field data in this study could be achieved with a more long-term focus group. Of course, even without the limitation of time, such a group could lend to bias in the case of having more prior knowledge on the company than just based on the campaign information we provided.

Second, the measures used for gauging moral identity internalization and symbolization were phrased definitively amidst large, overarching connectors between degrees of agreement with a statement and the person's moral identity as a whole but respectively lacked more subtle forms of recognition. More informal measures for symbolization could have been adapted with the importance of the internet in modern consumerism; online activism/support of companies in blogs or websites, communal discussions on forums, or similar engagements could provide interesting insight into certain effects in future research. Thinking about the importance of electronic word-of-mouth to the operation of modern businesses (see Park \& Lee, 2007 and 
Park, Yi, Kang, 2019) could be beneficial as a general principle for looking at subtleties in such measures. Using specificity amidst subtlety blended with modernity of times could provide unique value, especially in a fast-changing industry like fashion.

Third, in developing data on consumer admiration, we adapted Algoe and Haidt's (2009) approach in using a nine-point scale to gauge from "not at all" to "quite a lot." Revising this approach to yield more specific measures of admiration could also have included a recognition of respondents without enough knowledge on the topic or campaign to comfortably answer. Options like "N/A" or "I don't know" could have given more of a methodological push to remove extraneous responses that could have provided noise in our data. Future research should seek to develop, and mainly test, other metrics for evaluating consumer admiration that can be established as a standard for approaching that aspect of field data replication moving forward.

We expect that this research offers a unique look at the three-point system of moral identity, consumer admiration, and consumer practices and lays the foundation for new explorations into intra-dimensional factor variables between moral identity symbolization and internalization. Our research provides a more complete envisioning of ideal consumer-corporation interaction, however, for further implications, future research could inspect into cultural differences across the ethnic groups by using the model we tested with aggregate sample data under the theoretical consideration.

〈Received May 6. 2020〉

$\langle$ Accepted July 21. 2020〉

\section{References}

Aaker, J. L., Garbinsky, E. N., \& Vohs, K. D. (2012). Cultivating admiration in brands: Warmth, competence, and landing in the "golden quadrant". Journal of Consumer Psychology, 22(2), 191-194.

Ahn, S. (2015). The effect of luxury product pricing on consumers' perceptions about CSR activities. Academy of Marketing Studies Journal, 19(3), 1-14.

Aiken, L. S., West, S. G., \& Reno, R. R. (1991). Multiple regression: Testing and interpreting interactions. London: Sage Publications.

Algoe, S. B., \& Haidt, J. (2009). Witnessing excellence in action: The 'other-praising' emotions of elevation, gratitude, and admiration. The Journal of Positive Psychology, 4(2), 105-127.

Alhouti, S., Johnson, C. M., \& Holloway, B. B. (2016). Corporate social responsibility authenticity: Investigating its antecedents and outcomes. Journal of Business Research, 69(3), 1242-1249. 
Anderson, J. C., \& Gerbing, D. W. (1988), Structural equation modeling in practice: a review and recommended two-step approach. Psychology Bulletin, 103(3), 411-423.

Aquino, K., \& Reed, I. I. (2002). The selfimportance of moral identity. Journal of Personality and Social Psychology, 83(6), 1423-1440.

Barnett, M. L., Jermier, J. M., \& Lafferty, B.

A. 2006. Corporate reputation: The definitional landscape. Corporate Reputation Review, 9, 26-38.

Bass, B. M., \& Steidlmeier, P. (1999). Ethics, character and authentic transformational leadership behavior. The Leadership Quarterly, 10(2), 181-217.

Bélanger, J. J., Caouette, J., Sharvit, K., \& Dugas, M. (2014). The psychology of martyrdom: Making the ultimate sacrifice in the name of a cause. Journal of Personality and Social Psychology, 107(3), 494-515.

Bendana, A. (2002). Which ways for NGOs: A perspective from the South. Retrieved from https://www.transcend.org. Accessed date: 15 April 2020.

Bortree, D. S. (2009). The impact of green initiatives on environmental legitimacy and admiration of the organization. Public Relations Review, 35(2), 133-135.

Brown, T. J., \& Dacin, P. A. (1997). The company and the product: Corporate associations and consumer product responses. Journal of Marketing, 61(1), 68-84.

Burns, J. M. (1978). Leadership. New York: Harper and Row.

Carroll, A. B. (1991). The pyramid of corporate social responsibility: Toward the moral management of organizational stakeholders. Business Horizons, 34(4), 39-48.

Castro-González, S., Bande, B., Fernández-Ferrín, P., \& Kimura, T. (2019). Corporate social responsibility and consumer advocacy behaviors: the importance of emotions and moral virtues. Journal of Cleaner Production, 231(10), 846-855.

Cha, M. K., Yi, Y., \& Bagozzi, R. P. (2016). Effects of customer participation in corporate social responsibility (CSR) programs on the CSR-brand fit and brand loyalty. Cornell Hospitality Quarterly, 57(3), 235-249.

Choi, Y., \& Mai-Dalton, R. R. (1998). On the leadership function of self-sacrifice. The Leadership Quarterly, 9(4), 475-501.

Churchill, G. A. Jr, (1979). A paradigm for developing better measures of marketing constructs. Journal of Marketing Research, 16(1), 64-73.

Cone (2013). 2013 Cone Communications/echo global CSR study. Retrieved from http:// WWW.conecomm.com/2013-global-csrstudy-report. Accessed date: 10 June 2013.

De Cremer, D. (2006). Affective and motivational consequences of leader self-sacrifice: The moderating effect of autocratic leadership. The Leadership Quarterly, 17(1), 79-93. 
De Cremer, D., \& Knippenberg, D. (2005). Cooperation as a function of leader selfsacrifice, trust, and identification. Leadership and Organizational Development Journal, 26(5), 355-369.

De Roeck, K., \& Delobbe, N. (2012). Do environmental CSR initiatives serve organizations' legitimacy in the oil industry? Exploring employees' reactions through organizational identification theory. Journal of Business Ethics, 110(4), 397-412.

Dodd, E. M., Jr. (1932). For whom are corporate managers trustees? Harvard Law Review, 45, 1145-1163.

Du, S., Bhattacharya, C. B., \& Sen, S. (2007). Reaping relational rewards from corporate social responsibility: The role of competitive positioning. International Journal of Research in Marketing, 24(3), 224-241.

Du, S., Bhattacharya, C. B., \& Sen, S. (2010). Maximizing business returns to corporate social responsibility (CSR): The role of CSR communication. International Journal of Management Reviews, 12(1), 8-19.

Dugas, M., Bélanger, J. J., Moyano, M., Schumpe, B. M., Kruglanski, A. W., Gelfand, M. J., ... \& Nociti, N. (2016). The quest for significance motivates self-sacrifice. Motivation Science, 2(1), 15-32.

Esposito, M., Tse, T., \& Soufani, K. (2016). Companies are working with consumers to reduce waste. Harvard Business Review, June, 2-5.
Fornell, C. \& Larcker, D.F. (1981). Evaluating structural equation models with unobservable variables and measurement error. Journal of Marketing Research, 18(1), 39-50.

Fredrickson, B. L. (1998). What good are positive emotions? Review of General Psychology, 2(3), 300-319.

Frijda, N. H., Kuipers, P., \& ter Shure, E. (1989). Relations among emotion, appraisal and emotional action readiness. Journal of Personality and Social Psychology, 57(2), 212-228.

Gong, In Young (2017). Sustainable fashion is essential, not optional. Sustainable Journal, 8/1/2017. Retrieved from http://www. sjournal.kr/news/articleView.html?idxno $=477$.

Graziano, W. G., Habashi, M. M., Sheese, B. E. \& Tobin, R.M. (2007). Agreeableness, empathy, and helping: a person $\mathrm{X}$ situation perspective. Journal of Personality and Social Psychology, 93(4), 583-599.

Hayes, A. F. (2013). The PROCESS macro for SPSS and SAS (version 2.13) [Software]. He, H., Chao, M. M., \& Zhu, W. (2019). Cause-related marketing and employee engagement: The roles of admiration, implicit morality beliefs, and moral identity. Journal of Business Research, 95 (February), 83-92. Hoeffler, S. and Keller, K. L. (2002), "Building brand equity through corporate societal marketing," Journal of Public Policy \& Marketing, 21(1), 78-89. 
Hong, Y. M., \& Kim, Y. J. (2014). Attitudes of Korean college students toward upcycle fashion products. Journal of the Korean Society of Design Culture, 20(2), 207-218.

Howell, J. M., \& Avolio, B. J. (1992). The ethics of charismatic leadership: Submission or liberation? The Executive, 6(2), 43-52. Immordino-Yang, M. H., \& Sylvan, L. (2010). Admiration for virtue: Neuroscientific perspectives on a motivating emotion. Contemporary Educational Psychology, 35 (2), 110-115.

Jarvis, W., Ouschan, R., Burton, H., Soutar, G. \& O’Brien, I. (2017). Customer engagement in CSR: a utility theory model with moderating variables. Journal of Service Theory and Practice, 27(4), 833-853.

Jeong, S. J., \& Rhee, Y. J. (2014). A study on corporate social responsibility activities of fashion companies. Journal of the Korea Fashion \& Costume Design Association, 20(1), 17-28.

Joo, S., Miller, E. G., \& Fink, J. S. (2019). Consumer evaluations of CSR authenticity: Development and validation of a multidimensional CSR authenticity scale. Journal of Business Research, 98(May), 236-249.

Jöreskog, K. G., \& Sörbom, D. (1989). LISREL 7: A Guide to the Program and Applications. SPSS.

Wetherille, K. (2019). Patagonia: humble beginnings to planet defender. WWD.
Retrieved from https://wwd.com/business -news/business-features/patagonia-humble -beginnings-to-planet-defender-12030827 $25 /$.

Keltner, D., \& Haidt, J. (2003). Approaching awe, a moral, spiritual, and aesthetic emotion. Cognition and Emotion, 17(2), 297-314.

Kim, W. B., \& Choo, H. J. (2019). The effects of SNS fashion influencer authenticity on follower behavior intention: Focused on the mediation effect of fanship. Journal of Korean Society of Clothing and Textiles, 43(1), 17-32.

Kim, Y. (2017). Consumer responses to the food industry's proactive and passive environmental CSR, factoring in price as CSR tradeoff. Journal of Business Ethics, 140(2), 307-321.

Lazarus, R. S. (1991). Emotion and adaptation. New York: Oxford University Press.

Le Menestrel, M. (2002). Economic rationality and ethical behaviour: ethical business between venality and sacrifice. Business Ethics: A European Review, 11(2), 157166.

Lee, M. J., \& Ma, Y. J., \& Lee, M. S. (2017). Corporate social responsibility practices of the textiles and apparel industry: Content analysis of website disclosures. Journal of Fashion Business, 21(1), 45-57.

Lee, S. H., \& Kim, B. Y. (2011). A study on consumer attitudes toward socially responsibility 
fashion corporations. Journal of the Korean Society of Design Culture, 17(1), 424-434. Leleux, B., \& Van der Kaaij, J. (2018), Winning Sustainability Strategies: Finding Purpose, Driving Innovation and Executing Change, Palgrave MacMillan, Switzerland.

Line, N. D., Hanks, L., \& Zhang, L. (2018). Birds of a feather donate together: Understanding the relationship between the social servicescape and CSR participation. International Journal of Hospitality Management, 71(April), 102-110.

Little, T. D., Cunningham, W. A., Shahar, G., \& Widaman, K. F. (2002). To parcel or not to parcel: Exploring the question, weighing the merits. Structural Equation Modeling, 9(2), 151-173.

Lo, A. (2020). Effects of customer experience in engaging in hotels' CSR activities on brand relationship quality and behavioural intention. Journal of Travel \& Tourism Marketing, 37(2), 185-199.

Lockwood, P., \& Kunda, Z. (1997). Superstars and me: Predicting the impact of role models on the self. Journal of Personality and Social Psychology, 73(1), 91-103.

Lockwood, P., \& Kunda, Z. (1999). Increasing the salience of one's best selves can undermine inspiration by outstanding role models. Journal of Personality and Social Psychology, 76(2), 214-228.

Luthans, F., \& Avolio, B. J. (2003). Authentic leadership: A positive development approach.
In K. S. Cameron, J. E. Dutton, \& R. E. Quinn (Eds.), Positive Organizational Scholarship, 242-261. San Francisco, CA: Berrett-Koehler.

Mael, F., \& Ashforth, B. E. (1992). Alumni and their alma mater: A partial test of the reformulated model of organizational identification. Journal of Organizational Behavior, 13(2), 103-123.

Mattila, A. S., \& Hanks, L. (2012). Antecedents to participation in corporate social responsibility programs. Journal of Service Management, 23(5), 664-676.

Mattila, A., Wu, L. \& Choi, C. (2016), "Powerful or powerless customers: the influence of gratitude on engagement with CSR," Journal of Services Marketing, 30(5), 519-528.

Mazutis, D. D., \& Slawinski, N. (2014). Reconnecting business and society: Perceptions of authenticity in corporate social responsibility. Journal of Business Ethics, 131, 1-14.

McShane, L., \& Cunningham, P. (2012). To thine own self be true? Employees' judgments of the authenticity of their organization's corporate social responsibility program. Journal of Business Ethics, 108, 81-100.

Michie, S., \& Gooty, J. (2005). Values, emotions, and authenticity: Will the real leader please stand up?. The Leadership Quarterly, 16 (3), 441-457.

Murakami, K. (2009). Strategic CSR in Japan. Nomura Research Institute, Ltd., 1-15.

Novicevic, M. M., Davis, W., Dorn, F., Buckley, 
M. R., \& Brown, J. A. (2005). Barnard on conflicts of responsibility: Implications for today's perspectives on transformational and authentic leadership. Management Decision, 43(10), 1396-1409.

O’Hare, S. L., \& Wood, W. C. (1994). Social responsibility and corporate profits: The expense preference approach. Journal of Education for Business, 69(5), 278-282.

Olivola, C. Y., \& Shafir, E. (2013). The martyrdom effect: When pain and effort increase prosocial contributions. Journal of Behavioral Decision Making, 26(1), 91-105.

Ortony, A., Clore, G., \& Collins, A. (1988). The cognitive structure of emotions. New York: Cambridge University Press.

Patterson, L., \& Rowley, C. (2019). Ethical management and leadership: a conceptual paper and Korean example. Asian Journal of Business Ethics, 8(1), 1-24.

Pentecost, R., \& Andrews, L. (2010). Fashion retailing and the bottom line: The effects of generational cohorts, gender, fashion fanship, attitudes and impulse buying on fashion expenditure. Journal of Retailing and Consumer Services, 17(1), 43-52.

Peterson, D. K. (2004). The relationship between perceptions of corporate citizenship and organizational commitment. Business \& Society, 43(3), 296-319.

Pirsch, J., Gupta, S., \& Grau, S. L. (2007). A framework for understanding corporate social responsibility programs as a continuum:
An exploratory study. Journal of Business Ethics, 70(2), 125-140.

Ramdas, Kavita. (2011). "Philanthrocapitalism: Reflections on Politics and Policy Making." Society, 48, 393-396.

Rich, B. L., Lepine, J. A., \& Crawford, E. R. (2010). Job engagement: Antecedents and effects on job performance. Academy of Management Journal, 53(3), 617-635.

Ruiz de Maya, S., Lardín-Zambudio, R., \& López-López, I. (2016). I will do it if I enjoy it: The moderating effect of seeking sensory pleasure when exposed to participatory CSR campaigns. Frontiers in Psychology, 6(1940), 1-10.

Ryan, R. M., \& Deci, E. L. (2000). Selfdetermination theory and the facilitation of intrinsic motivation, social development, and well-being. American Psychologist, 55 (1), 68-78.

Sen, S., Du, S. \& Bhattacharya, C.B. (2009), "Building relationships through corporate social responsibility," in MacInnis, D.J., Park, C.W. and Priester, J.R. (Eds), Handbook of Brand Relationships, M.E. Sharpe, Armonk, NY, 195-211.

Thorelli, R. (2016). Providing Clarity for Standard of Conduct for Directors Within Benefit Corporations: Requiring Priority of a Specific Public Benefit. Minnesota Law Review, 101, 1749-1789.

Thrash, T. M., \& Elliot, A. J. (2004). Inspiration: Core characteristics, component processes, 
antecedents, and function. Journal of Personality and Social Psychology, 87(6), 957-973.

Winterich, K. P., Aquino, K., Mittal, V., \& Swartz, R. (2013). When moral identity symbolization motivates prosocial behavior: The role of recognition and moral identity internalization. Journal of Applied Psychology, 98(5), 759-770.

Xie, C., Bagozzi, R. P., \& Grønhaug, K. (2015). The role of moral emotions and individual differences in consumer responses to corporate green and non-green actions. Journal of the Academy of Marketing Science, 43(3), 333-356.

Yoo, H. S. (2012). Ethical fashion in the fashion industry: focusing on the actualization of sustainable fashion. Journal of the Korean Society of Fashion Design, 12(2), 39-57. Yorges, S. L., Weiss, H. M., \& Strickland, O. J. (1999). The effect of leader outcomes on influence, attributions, and perceptions of charisma. Journal of Applied Psychology, 84(3), 428-436. 


\section{$\langle$ Appendix〉}

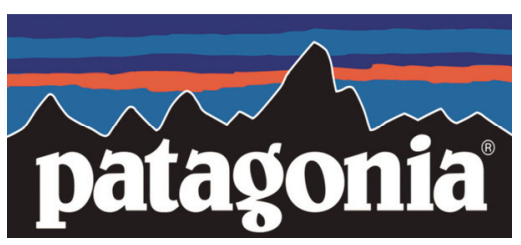

\section{Patagonia}

Patagonia divides their work for environmental and social responsibility into three main categories: their identity as an "activist company," environmental impact, and supply chain. The campaigns are driven by their strong spirits; U.S. President Trump's tax cut from a few years back granted a refund of $\$ 10$ million to the company, which immediately announced a plan to fight for environmental causes threatened by the tax cut in the first place.

Furthermore, Patagonia has had two major initiatives, One Percent for the Planet and Patagonia Action Works. Patagonia's founder decided to donate one percent of their revenue for environmental sustainability and started One Percent in 2002, which has since gathered over \$225 million for environmental nonprofits.' ${ }^{1}$ Action Works has supported grantees with over $\$ 100$ million since 1985 to work in areas of land, water, climate, and biodiversity.'

The company has consistently encouraged customers to think before they buy; in 2011 they posted an ad of a fleece with "don't buy this jacket" written underneath, symbolizing their mission for sustainable purchasing. Patagonia vests have also long been a trademark of top finance firms, but nowadays only selectively partners with sustainable companies.

Patagonia has also focused since 2005 on Worn Wear, an online store for used Patagonia clothing that stresses extending the life of their used gear through repair and recycling to cut down on consumption. ${ }^{3)}$ Patagonia also offers a free recycling service for all their clothing, guaranteeing that any of their customers' old Patagonia clothing will not end up in landfills or incinerators but rather will be recycled and repurposed. (4) The company takes the motto "If it's broke, fix it!" quite seriously and made 50,295 clothing repairs in its Reno, Nevada center alone during 2017.5)

For more information, you may visit the web site. (https://wornwear.patagonia.com/)

1) https://www.onepercentfortheplanet.org/about

2) https://www.patagonia.com/actionworks/about/

3) https://wornwear.patagonia.com/

4) https://www.patagonia.com/recycling.html

5) https://www.washingtonpost.com/business/inside-patagonias-operation-to-keep-you-from-buying-new-gear/2018/08/31/ d3d1fab4-ac8c-11e8-b1da-ff7faa680710_story.html 